\title{
Pre-Pegmatite Stage in Peralkaline Magmatic Process: Insights from Poikilitic Syenites from the Lovozero Massif, Kola Peninsula, Russia
}

\author{
Julia A. Mikhailova *, Yakov A. Pakhomovsky, Olga F. Goychuk, Andrey O. Kalashnikov (D, Ayya V. Bazai \\ and Victor N. Yakovenchuk
}

Citation: Mikhailova, J.A.; Pakhomovsky, Y.A.; Goychuk, O.F.; Kalashnikov, A.O.; Bazai, A.V.; Yakovenchuk, V.N. Pre-Pegmatite Stage in Peralkaline Magmatic Process: Insights from Poikilitic Syenites from the Lovozero Massif, Kola Peninsula, Russia. Minerals 2021 11,974. https://doi.org/10.3390/ $\min 11090974$

Academic Editor: Silvio

Giuseppe Rotolo

Received: 12 August 2021

Accepted: 4 September 2021

Published: 7 September 2021

Publisher's Note: MDPI stays neutral with regard to jurisdictional claims in published maps and institutional affiliations.

Copyright: (c) 2021 by the authors. Licensee MDPI, Basel, Switzerland. This article is an open access article distributed under the terms and conditions of the Creative Commons Attribution (CC BY) license (https:/ / creativecommons.org/licenses/by/ $4.0 /)$.
Geological Institute of the Kola Science Centre, Russian Academy of Sciences, 14 Fersman Street, 184209 Apatity, Russia; pakhom@geoksc.apatity.ru (Y.A.P.); olga.goychuk97@mail.ru (O.F.G.); kalashnikov@geoksc.apatity.ru (A.O.K.); bazai@geoksc.apatity.ru (A.V.B.);

yakovenchuk@geoksc.apatity.ru (V.N.Y.)

* Correspondence: mikhailova@geoksc.apatity.ru; Tel.: +7-81555-79333

\begin{abstract}
The Lovozero peralkaline massif (Kola Peninsula, Russia) is widely known for its unique mineral diversity, and most of the rare metal minerals are found in pegmatites, which are spatially associated with poikilitic rocks (approximately $5 \%$ of the massif volume). In order to determine the reasons for this relationship, we have investigated petrography and the chemical composition of poikilitic rocks as well as the chemical composition of the rock-forming and accessory minerals in these rocks. The differentiation of magmatic melt during the formation of the rocks of the Lovozero massif followed the path: lujavrite $\rightarrow$ foyaite $\rightarrow$ urtite (magmatic stage) $\rightarrow$ pegmatite (hydrothermal stage). Yet, for peralkaline systems, the transition between magmatic melt and hydrothermal solution is gradual. In the case of the initially high content of volatiles in the melt, the differentiation path was probably as follows: lujavrite $\rightarrow$ foyaite (magmatic stage) $\rightarrow$ urtitization of foyaite $\rightarrow$ pegmatite (hydrothermal stage). Poikilitic rocks were formed at the stage of urtitization, and we called them pre-pegmatites. Indeed, the poikilitic rocks have a metasomatic texture and, in terms of chemical composition, correspond to magmatic urtite. The reason for the abundance of rare metal minerals in pegmatites associated with poikilitic rocks is that almost only one nepheline is deposited during urtitization, whereas during the magmatic crystallization of urtite, rare elements form accessory minerals in the rock and are less concentrated in the residual solution.
\end{abstract}

Keywords: Lovozero massif; peralkaline rocks; pegmatites; autometasomatic alteration

\section{Introduction}

Pegmatites form at the final stage of the magmatic process with the participation of late magmatic fluids. Most pegmatites are mineralogically simple, essentially very coarse rocks. Others contain a tremendous concentration of incompatible elements and a highly varied mineralogy, commonly displaying a concentric zonation (see e.g., [1-4]). As the late fluid segregation concentrates trace elements, pegmatites are important economic resources and are mined for $\mathrm{Li}$, Be, the rare earth elements (REE), W, Zr, and a host of other elements that are rarely concentrated in other environments $[5,6]$. They are also a major source of gems.

Pegmatite genesis is a subject of controversy. One school of thought (see, e.g., [7,8]) proposes that they are the crystallization products of residual melts intruding fractures in country rocks. Such residual melts are relatively rich in volatiles $\left(\mathrm{H}_{2} \mathrm{O}, \mathrm{F}, \mathrm{Cl}\right.$, etc.). A different origin has been proposed by other researchers (see, e.g., $[1,9,10]$ ). Their interpretation is based on the frequent chaotic structure of the pegmatite veins, in which recrystallization phenomena are widespread, with resorption and chemical substitution of earlier-crystallized minerals. In this scenario, pegmatites result from profound transfor- 
mation of felsic rocks under the influence of hydrothermal solutions, rather than by direct magmatic crystallization.

Peralkaline igneous rocks are not widespread in the earth's crust [11], but they are of great interest to researchers because these rocks concentrate rare earth elements (REEs), high field strength elements (HFSEs, such as $\mathrm{Zr}, \mathrm{Hf}, \mathrm{Nb}, \mathrm{Ta}$, and $\mathrm{U}$ ), halogens and other volatiles $\left(\mathrm{F}, \mathrm{Cl}, \mathrm{S}, \mathrm{H}_{2} \mathrm{O}\right)$, and otherwise rare elements, such as $\mathrm{Be}, \mathrm{Sn}$, and $\mathrm{Zn}[12,13]$. In the process of crystallization of peralkaline rocks, it is believed that a gradual transition from magmatic melt to hydrothermal solution occurs [14-17]. The reason for such gradual transition is the high solubility of water in a peralkaline silicate melt. Water dissolves in a silicate melt both in molecular form and in the form of OH-groups, which are formed as a result of this reaction [18-20]:

$$
\mathrm{Si}-\mathrm{O}-\mathrm{Si}+\mathrm{H}_{2} \mathrm{O} \rightarrow \mathrm{Si}-\mathrm{OH}+\mathrm{OH}-\mathrm{Si}
$$

An increase in the content of alkaline elements $(\mathrm{Na}, \mathrm{K})$ in the melt increases the solubility of water because the following reactions occur $[19,21]$ :

$$
\begin{gathered}
\mathrm{Si}-\mathrm{O}-\mathrm{M}+\mathrm{H}_{2} \mathrm{O} \rightarrow \mathrm{Si}-\mathrm{OH}+\mathrm{OH}-\mathrm{M} \\
\mathrm{M}-\mathrm{O}-\mathrm{M}+\mathrm{H}_{2} \mathrm{O} \rightarrow 2 \mathrm{OH}-\mathrm{M}
\end{gathered}
$$

where $\mathrm{M}$ is a metal, e.g., $\mathrm{Na}$.

At the same time, the $\mathrm{H}_{2} \mathrm{O} / \mathrm{OH}$ ratio increases with an increase in the total water content $[18,22]$. The evolution of a peralkaline melt goes in the direction of sodium enrichment $[14,23,24]$; therefore, more and more water can dissolve in it. Thus, there is a gradual transition from a magmatic silicate melt, in which the main component is $\mathrm{SiO}_{4}$, to a hydrothermal solution, where the main component is water. Therefore, for peralkaline rocks, it is impossible to clearly distinguish between pegmatites and hydrothermal veins [25], and to describe the processes of differentiation in peralkaline systems, researchers sometimes use mixed terms, such as melt-solution [14], melt/fluid [26] or fluid/melt [17]. A highly evolved melt-solution saturated with $\mathrm{Na}$ and incompatible elements can: (1) form pegmatites and hydrothermal veins; (2) induce intense fenitization of the surrounding rocks; (3) remain in the crystallizing rock and cause extensive autometasomatic alterations. In this article, we suggest an additional path for the above-mentioned melt-solution. We believe that a highly evolved melt-solution can (4) change its composition as a result of autometasomatic alterations and then form pegmatites and hydrothermal veins.

The object of our research was the Lovozero peralkaline massif (Kola Peninsula, Russia). It is widely known for its unique mineral diversity, as the massif is a type locality for 106 minerals, and the total number of minerals known there is 393 species (https: / www. mindat.org/loc-2697.html, accessed on 6 September 2021). The maximal mineral diversity is typical for pegmatites and hydrothermal veins [25]. There are more than 1000 pegmatites in the Lovozero massif $[25,27,28]$. There are both simple pegmatites, which are coarsegrained analogs of the host rocks, and extremely complex ones, containing a wide variety of rare minerals. For example, 58 minerals were found in the Yubileinaya pegmatite, which is the type locality for 13 of them; 63 minerals were found in the Sirenevaya pegmatite; and 46 minerals were found in pegmatite (no. 47 in accordance with Semenov's [28] numbering) on Mount Lepkhe-Nel'm [25].

In the Lovozero massif, pegmatites containing a wide variety of rare-metal $(\mathrm{Li}, \mathrm{Be}$, $\mathrm{Ti}, \mathrm{Zr}, \mathrm{Nb}, \mathrm{Ta}, \mathrm{REE})$ mineralizations are found in two main settings. Such pegmatites are found (1) in urtite of the Layered complex or (2) spatially associated with the rocks of the so-called poikilitic complex [27,28]. Even though poikilitic rocks in the Lovozero massif are not widespread ( $5 \%$ of the massif volume), most of the rare metal pegmatites are confined to these rocks. Besides, pegmatites associated with rocks of the poikilitic complex are characterized by the greatest variety of lithium, beryllium, and rare-earth minerals. The main distinguishing feature of poikilitic rocks is the presence of very large crystals of orthoclase with numerous inclusions of feldspathoids. They usually form isolated lenses 
or sheet-like bodies and are a prospecting criterium for rare-metal pegmatites in field investigations.

Vlasov et al. [27] stated that rocks of the poikilitic complex represent a pegmatoid stage in evolution of the Lovozero massif and were formed as a result of crystallization of a highly evolved melt enriched in volatile components and rare elements. According to Bussen and Sakharov [29], Gerasimovsky [30], Arzamastsev [31], the rocks of the poikilitic complex are the earliest rocks of the massif. These researchers suggested that the poikilitic complex formed as a separate magmatic phase and was preserved as xenoliths among younger rocks, which make up the bulk volume of the massif.

In this article, we suggest a possible mechanism of the formation of the poikilitic complex rocks and the potential reasons for their spatial association with pegmatites enriched in rare metal minerals. We support the conclusions of Vlasov et al. [27] and propose to consider the studied rocks as pre-pegmatites. In our opinion, the poikilitic rocks of the Lovozero massif are evidence of a unique feature of the peralkaline systems, namely, the gradual transition from magmatic melt to hydrothermal solution [14,15].

Poikilitic rocks are known not only in the Lovozero massif, but also in other peralkaline massifs of the world. In the Khibiny massif (Russia), a similar rock is called rischorrite [32,33], and it is located at the contact of nepheline syenite (foyaite), which composes the bulk of the massif, and foidolite, which composes an annular intrusion (the so-called Main Ring). It is important to note that most of the pegmatites of the Khibiny massif are located at the contact of rischorrite and foyaite [34]. In the Ilímaussaq massif (Greenland), rocks consisting mainly of feldspar with inclusions of sodalite are called naujaite. This rock is part of the layered roof series and is associated with the foyaite and pulaskite $[35,36]$. Conformable pegmatite layers are particularly well developed in the naujaite $[17,35]$. In the Mont Saint Hilaire massif (Canada), sodalite-rich foid syenite, consisting of poikilitic feldspar with inclusions of sodalite and nepheline, occurs as centimeter- to meter-sized inclusions in fine-grained porphyritic foid syenites and nepheline sienite [37]. Sodalite-rich foid syenite in the Mont Saint Hilaire massif is a host mineral characteristic to pegmatites (e.g., natrolite, villiaumite, astrophyllite) and is spatially related to pegmatites [38].

\section{Geological Setting and Previous Works}

The Lovozero peralkaline massif is located on the Kola Peninsula (Russia) (Figure 1a) and covers an area of $650 \mathrm{~km}^{2}$. This layered laccolith-type pluton was emplaced at 360-370 Ma [39-41] into Archean granite gneiss covered by Devonian volcaniclastic rocks [42]. A large number of studies are devoted to geology, petrology (e.g., [27,29,30,43-46]), as well as mineralogy of this massif (e.g., [25,28,47-52]).

The Lovozero massif consists of two main units (Figure 1b): Layered and Eudialyte complexes. The Layered complex makes up 77\% of the massif volume [30], has a thickness of more than $1700 \mathrm{~m}$, and consists of many layers (or rhythms). The dip angles of the layers are 5-350 to the center of the massif. The idealized rhythm is a sequence of rocks (top to bottom): lujavrite-foyaite-urtite. Lujavrite is a trachytoid (i.e., with subparallel feldspar laths) meso- or melanocratic nepheline syenite; foyaite is a massive, less often weakly trachytoid, leucocratic nepheline syenite; urtite is an almost monomineral nepheline rock of massive texture. The mineral and modal compositions and textures of different rocks of the Layered complex are summarized in Table 1. The transition between rocks within the rhythm is gradual, and contacts between rhythms are sharp. Pegmatites are associated with urtite. Pegmatites form lenses at the contacts of rhythms, while the underlying lujavrite is almost completely unchanged, and the overlying urtite contains numerous apophyses of pegmatite. The thicknesses of each of the three types of rocks (lujavrite, foyaite, or urtite) correlates with the thickness of the entire rhythm. Such rhythms are found only in the upper zone of the Layered complex (Figure 1c). The middle part of this complex consists of lujavrite with foyaite lenses, and the lower part consists of lujavrite-foyaite rhythms with urtite lenses. 


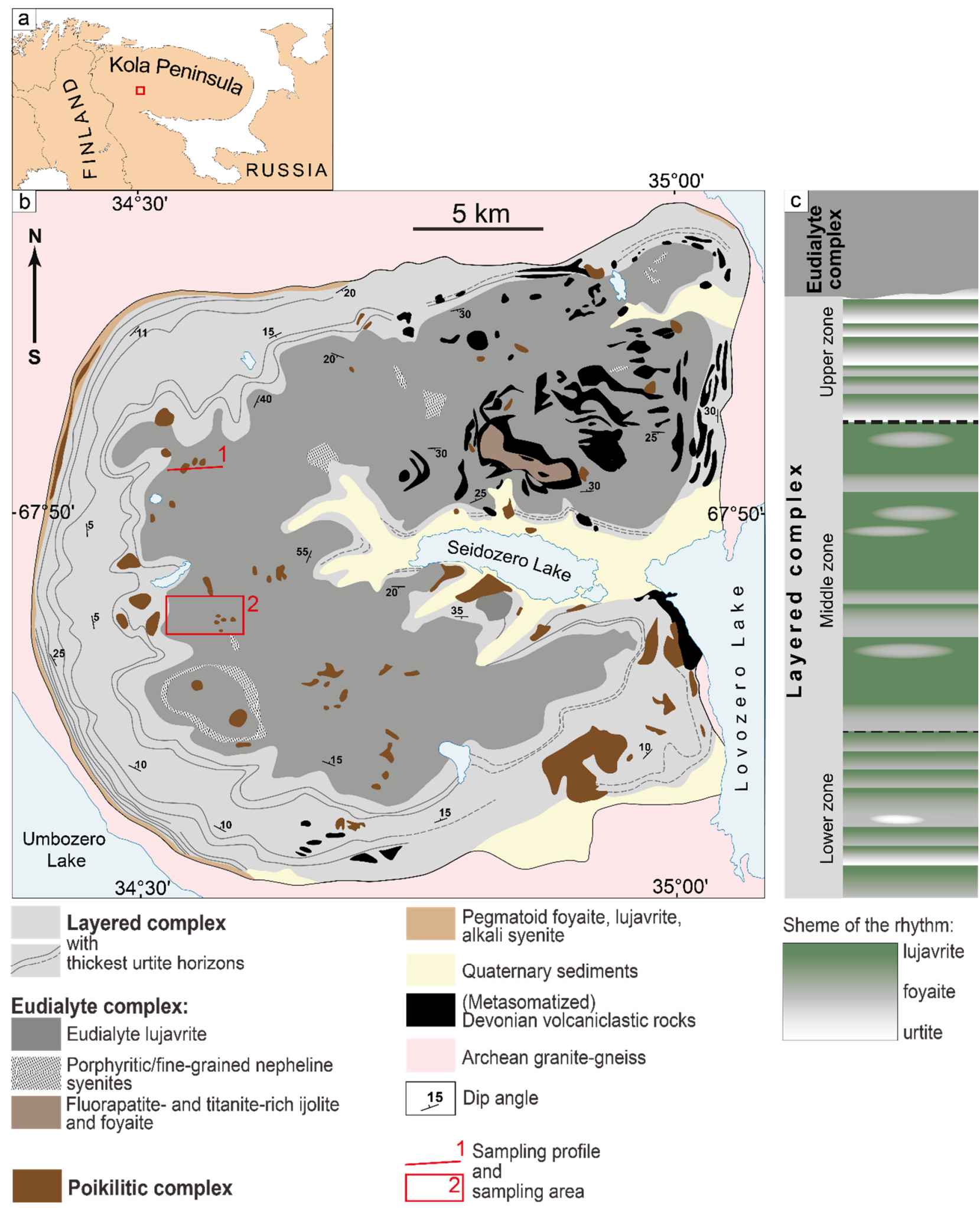

Figure 1. (a) Location of the Lovozero massif within the Kola Peninsula (red square); (b) geological scheme of the Lovozero massif (adapted from [29]); and (c) schematic cross-section of the Eudialyte and Layered complexes.

The Eudialyte complex is located in the upper part of the Lovozero massif (Figure 1b,c) and occupies $18 \%$ of its volume [30]. The thickness of this complex is from 100 (in the east) to $800 \mathrm{~m}$ (in the north-west). The main rock of the Eudialyte complex is lujavrite enriched in eudialyte-group minerals (EGM), the so-called eudialyte lujavrite. Among eudialyte 
lujavrite, lenses and layers of foyaite, as well as fine-grained and porphyritic nepheline syenites (Table 1), are irregularly located.

Table 1. Summary of the petrography of the Layered and Eudialyte complexes.

\begin{tabular}{|c|c|c|c|c|c|}
\hline Complex & Rock & $\begin{array}{c}\text { Rock-Forming Minerals } \\
\text { (Average Content, Modal \%) }\end{array}$ & $\begin{array}{c}\text { Characteristic Accessory } \\
\text { Minerals }{ }^{1}\end{array}$ & Texture & $\begin{array}{l}\% \text { in } \\
\text { Complex } \\
\text { Volume } \\
\text { [30] }\end{array}$ \\
\hline \multirow{3}{*}{$\begin{array}{l}\text { Layered } \\
\text { complex }\end{array}$} & Lujavrite & $\begin{array}{l}\text { Euhedral microcline perthite }(45), \\
\text { euhedral to anhedral nepheline } \\
\text { + secondary natrolite (20), } \\
\text { euhedral aegirine (25), anhedral } \\
\text { magnesio-arfvedsonite (5) }\end{array}$ & $\begin{array}{l}\text { EGM }^{2} \text {, lamprophyllite, sodalite, } \\
\text { loparite-(Ce), } \\
\text { barytolamprophyllite, sphalerite, } \\
\text { fluorapatite, lorenzenite }\end{array}$ & $\begin{array}{l}\text { Trachytoid; } \\
\text { coarse- to } \\
\text { medium- } \\
\text { grained }\end{array}$ & 53 \\
\hline & Foyaite & $\begin{array}{l}\text { Euhedral to subhedral microcline } \\
\text { perthite }(50) \text {, euhedral to anhedral } \\
\text { nepheline + secondary natrolite ( } 35) \text {, } \\
\text { anhedral or poikilitic aegirine (7) }\end{array}$ & $\begin{array}{c}\text { Magnesio-arfvedsonite, EGM, } \\
\text { sodalite, lamprophyllite, } \\
\text { sphalerite, } \\
\text { loparite-(Ce), murmanite, } \\
\text { lomonosovite }\end{array}$ & $\begin{array}{l}\text { Massif to weakly } \\
\text { trachytoid; coarse- to } \\
\text { medium-grained }\end{array}$ & 42 \\
\hline & Urtite & $\begin{array}{l}\text { Euhedral to anhedral nepheline }+ \\
\text { secondary natrolite }(70) \text {, euhedral to } \\
\text { subhedral microcline perthite }(12), \\
\text { anhedral sodalite (7), poikilitic } \\
\text { aegirine (6) }\end{array}$ & $\begin{array}{l}\text { Loparite-(Ce), fluorapatite, EGM, } \\
\text { magnesio-arfvedsonite, titanite, } \\
\text { murmanite, sphalerite }\end{array}$ & $\begin{array}{c}\text { Massif; } \\
\text { coarse- to } \\
\text { medium-grained }\end{array}$ & 5 \\
\hline \multirow{3}{*}{$\begin{array}{l}\text { Eudialyte } \\
\text { complex }\end{array}$} & $\begin{array}{l}\text { Eudialyte } \\
\text { lujavrite }\end{array}$ & $\begin{array}{c}\text { Euhedral microcline (36), } \\
\text { euhedral to subhedral EGM (25), } \\
\text { euhedral aegirine (20), euhedral to } \\
\text { anhedral nepheline + secondary } \\
\text { natrolite (15), anhedral } \\
\text { magnesio-arfvedsonite (5) }\end{array}$ & $\begin{array}{c}\text { Sodalite, loparite-(Ce), } \\
\text { lamprophyllite, } \\
\text { barytolamprophyllite, sphalerite }\end{array}$ & $\begin{array}{l}\text { Trachytoid; coarse- to } \\
\text { medium-grained }\end{array}$ & 80 \\
\hline & Foyaite & $\begin{array}{l}\text { Euhedral to subhedral } \\
\text { microclineperthite (55), euhedral to } \\
\text { subhedral nepheline + secondary } \\
\text { natrolite (35), anhedral or poikilitic } \\
\text { aegirine (7) }\end{array}$ & $\begin{array}{l}\text { Magnesio-arfvedsonite, } \\
\text { fluorapatite, sodalite, } \\
\text { lovozerite-group minerals, EGM, } \\
\text { murmanite, lomonosovite }\end{array}$ & $\begin{array}{l}\text { Massif to weakly } \\
\text { trachytoid; } \\
\text { coarse- to } \\
\text { medium-grained }\end{array}$ & 10 \\
\hline & $\begin{array}{l}\text { Porphyritic/fine- } \\
\text { grained } \\
\text { nepheline } \\
\text { syenites }\end{array}$ & $\begin{array}{l}\text { Fine-grained mass: euhedral albite } \\
(25), \text { anhedral microcline }(25), \\
\text { anhedral nepheline }(20) \text {, euhedral } \\
\text { aegirine (20), anhedral or poikilitic } \\
\text { magnesio-arfvedsonite }(5) \\
\text { Phenocrysts: nepheline }(0-20 \%), \\
\text { microcline perthite }(0-35 \%)\end{array}$ & $\begin{array}{l}\text { EGM, lovozerite-group minerals, } \\
\text { sodalite, murmanite, } \\
\text { lamprophyllite }\end{array}$ & $\begin{array}{l}\text { Porphyritic/fine- } \\
\text { grained }\end{array}$ & 10 \\
\hline
\end{tabular}

A large number of xenoliths of Devonian volcaniclastic rocks [30,42], both unaltered and intensely metasomatized (fenitized), are found among the rocks of the Layered and Eudialyte complexes. Unaltered xenoliths are composed of olivine basalt, basalt tuff, tuffite, and sandstone. Alkaline lamprophyre dikes up to $5 \mathrm{~m}$ thick are most common in the northwest and south of the Lovozero massif.

Poikilitic complex (or complex of poikilitic syenites) is a collective name for a group of rocks diverse in mineral and modal composition [28-30,53]. The rocks of this complex occupy approximately $5 \%$ of the massif volume; they form lenses, sheet-like or irregularly shaped bodies with sizes of $10 \mathrm{~km} \times 0.5 \mathrm{~km}$ to $50 \mathrm{~cm} \times 30 \mathrm{~cm}$, which are located in both the Layered and Eudialyte complexes (Figure 1b). The main features of the rocks of the poikilitic complex are the presence of large (up to $15 \mathrm{~cm}$ in length) crystals of feldspar with numerous inclusions of feldspathoids (sodalite, nepheline, cancrinite, vishnevite), as well as metasomatic texture. The amount of poikilitic crystals of feldspar varies from single grains to $90 \%$ of the rock volume. In the poikilitic complex, the following main groups of rocks are recognized $[29,30]$ :

1. Uneven-grained nepheline syenite (poikilitic feldspar is rare, the main foid is nepheline) the name of this rock reflects that the size of the grains of the rock-forming nepheline varies greatly (from $50 \mu \mathrm{m}$ to $2 \mathrm{~cm}$ across); 
2. Poikilitic foid syenite (a large number of poikilitic feldspar crystals; the main foid can be different, e.g., vishnevite, cancrinite, sodalite).

For brevity's sake, in the following text, we will use the term poikilitic rocks instead of rocks of the poikilitic complex as a general name for these two types of rocks.

According to Bussen and Sakharov [29], the boundaries between uneven-grained nepheline syenite and poikilitic foid syenite are gradual. These rocks can either be found together in the volume of one body or form separate independent bodies.

The contacts of the poikilitic rocks with surrounded rocks of the Layered or Eudialyte complex are diverse. The contact of uneven-grained nepheline syenite with lujavrite is sharp and the contact with foyaite is either sharp or gradual. At the contact of poikilitic foid syenite with lujavrite, there is a transition zone consisting of a large (up to $10 \mathrm{~cm}$ in length) microcline crystals (without poikilitic inclusions) and monomineral aegirine segregations. This zone is enriched in EGM, lorenzenite, murmanite, lamprophyllite, and rinkite-(Ce). Lujavrite lacks a trachytoid texture near the contact (in a zone up to $0.5 \mathrm{~m}$ wide) with poikilitic rocks.

Pegmatites are found both at the contact of poikilitic rocks with surrounded rocks (Figure $2 \mathrm{a}, \mathrm{b}$ ) and within bodies of poikilitic rocks (Figure 2c). The transition between poikilitic rocks and pegmatites is gradual. Table 2 lists the rare metal minerals (for example see Figure $2 \mathrm{~d}$,e) characteristic to pegmatites spatially associated with poikilitic rocks according to Pekov [25] and Semenov [28].

Table 2. List of rare metal minerals from pegmatites spatially related to poikilitic rocks $[25,28]$.

\begin{tabular}{|c|c|}
\hline Mineral & Formula ${ }^{1}$ \\
\hline Belovite-(Ce) & $\mathrm{NaCeSr}_{3}\left(\mathrm{PO}_{4}\right)_{3} \mathrm{~F}$ \\
\hline Bertrandite & $\mathrm{Be}_{4} \mathrm{Si}_{2} \mathrm{O}_{7}(\mathrm{OH})_{2}$ \\
\hline Beryllite & $\mathrm{Be}_{3}\left(\mathrm{SiO}_{4}\right)(\mathrm{OH})_{2} \cdot \mathrm{H}_{2} \mathrm{O}$ \\
\hline Bornemanite & $\mathrm{Na}_{6}(\mathrm{Na} \square) \mathrm{Ba}_{2} \mathrm{Ti}_{2} \mathrm{Nb}_{2}\left(\mathrm{Si}_{2} \mathrm{O}_{7}\right)_{4}\left(\mathrm{PO}_{4}\right)_{2} \mathrm{O}_{4}(\mathrm{OH})_{2} \mathrm{~F}_{2}$ \\
\hline Chkalovite & $\mathrm{Na}_{2} \mathrm{BeSi}_{2} \mathrm{O}_{6}$ \\
\hline Epididymite (Figure 2d) & $\mathrm{Na}_{2} \mathrm{Be}_{2} \mathrm{Si}_{6} \mathrm{O}_{15} \cdot \mathrm{H}_{2} \mathrm{O}$ \\
\hline Karnasurtite-(Ce) & $\mathrm{CeTiAlSi}{ }_{2} \mathrm{O}_{7}(\mathrm{OH})_{4} \cdot 3 \mathrm{H}_{2} \mathrm{O}$ \\
\hline Kupletskite & $\mathrm{K}_{2} \mathrm{NaMn}^{2+}{ }_{7} \mathrm{Ti}_{2}\left(\mathrm{Si}_{4} \mathrm{O}_{12}\right)_{2} \mathrm{O}_{2}(\mathrm{OH})_{4} \mathrm{~F}$ \\
\hline Lemmleinite-Ba & $\mathrm{Na}_{4} \mathrm{~K}_{4} \mathrm{Ba}_{2+\mathrm{x}} \mathrm{Ti}_{8}\left(\mathrm{Si}_{4} \mathrm{O}_{12}\right)_{4}(\mathrm{OH}, \mathrm{O})_{8} \cdot 8 \mathrm{H}_{2} \mathrm{O}$ \\
\hline Lemmleinite-K & $\mathrm{Na}_{4} \mathrm{~K}_{8} \mathrm{Ti}_{8}\left(\mathrm{Si}_{4} \mathrm{O}_{12}\right)_{4}(\mathrm{OH}, \mathrm{O})_{8} \cdot 8 \mathrm{H}_{2} \mathrm{O}$ \\
\hline Lepkhenelmite-Zn & $\mathrm{Ba}_{2} \mathrm{Zn}(\mathrm{Ti}, \mathrm{Nb})_{4}\left(\mathrm{Si}_{4} \mathrm{O}_{12}\right)_{2}(\mathrm{O}, \mathrm{OH})_{4} \cdot 7 \mathrm{H}_{2} \mathrm{O}$ \\
\hline Leucophanite & $\mathrm{NaCaBeSi}_{2} \mathrm{O}_{6} \mathrm{~F}$ \\
\hline Lintisite & $\mathrm{Na}_{3} \mathrm{LiTi}_{2} \mathrm{O}_{2}\left(\mathrm{SiO}_{3}\right)_{4} \cdot 2 \mathrm{H}_{2} \mathrm{O}$ \\
\hline Lorenzenite & $\mathrm{Na}_{2} \mathrm{Ti}_{2} \mathrm{O}_{3}\left(\mathrm{Si}_{2} \mathrm{O}_{6}\right)$ \\
\hline Manganoneptunite & $\mathrm{KNa}_{2} \mathrm{LiMn}^{2+}{ }_{2} \mathrm{Ti}_{2} \mathrm{Si}_{8} \mathrm{O}_{24}$ \\
\hline Monazite-(Ce) & $\mathrm{Ce}\left(\mathrm{PO}_{4}\right)$ \\
\hline Mosandrite-(Ce) & $\left(\mathrm{Ca}_{3} \mathrm{REE}\right)\left[\left(\mathrm{H}_{2} \mathrm{O}\right)_{2} \mathrm{Ca}_{0.5} \square_{0.5}\right] \mathrm{Ti}\left(\mathrm{Si}_{2} \mathrm{O}_{7}\right)_{2}(\mathrm{OH})_{2}\left(\mathrm{H}_{2} \mathrm{O}\right)$ \\
\hline Neptunite & $\mathrm{KNa}_{2} \mathrm{LiFe}^{2+}{ }_{2} \mathrm{Ti}_{2} \mathrm{Si}_{8} \mathrm{O}_{24}$ \\
\hline Polylithionite & $\mathrm{KLi}_{2} \mathrm{AlSi}_{4} \mathrm{O}_{10} \mathrm{~F}_{2}$ \\
\hline Rhabdophane-(Ce) & $\mathrm{Ce}\left(\mathrm{PO}_{4}\right) \cdot \mathrm{H}_{2} \mathrm{O}$ \\
\hline Sazhinite-(Ce) & $\mathrm{Na}_{3} \mathrm{CeSi}_{6} \mathrm{O}_{15} \cdot 2 \mathrm{H}_{2} \mathrm{O}$ \\
\hline Steenstrupine-(Ce) & $\mathrm{Na}_{14} \mathrm{Ce}_{6} \mathrm{Mn}^{2+}{ }_{2} \mathrm{Fe}^{3+}{ }_{2} \mathrm{Zr}\left(\mathrm{PO}_{4}\right)_{7} \mathrm{Si}_{12} \mathrm{O}_{36}(\mathrm{OH})_{2} \cdot 3 \mathrm{H}_{2} \mathrm{O}$ \\
\hline Tainiolite & $\mathrm{KLiMg}_{2} \mathrm{Si}_{4} \mathrm{O}_{10} \mathrm{~F}_{2}$ \\
\hline Tsepinite-Na & $\left(\mathrm{Na}, \mathrm{H}_{3} \mathrm{O}, \mathrm{K}, \mathrm{Sr}, \mathrm{Ba}, \square\right)_{2}(\mathrm{Ti}, \mathrm{Nb})_{2}\left(\mathrm{Si}_{4} \mathrm{O}_{12}\right)(\mathrm{OH}, \mathrm{O})_{2} \cdot 3 \mathrm{H}_{2} \mathrm{O}$ \\
\hline Tsepinite-Sr & $(\mathrm{Sr}, \mathrm{Ba}, \mathrm{K})(\mathrm{Ti}, \mathrm{Nb})_{2}\left(\mathrm{Si}_{4} \mathrm{O}_{12}\right)(\mathrm{OH}, \mathrm{O})_{2} \cdot 3 \mathrm{H}_{2} \mathrm{O}$ \\
\hline Tundrite-(Ce) & $\mathrm{Na}_{2} \mathrm{Ce}_{2} \mathrm{TiO}_{2}\left(\mathrm{SiO}_{4}\right)\left(\mathrm{CO}_{3}\right)_{2}$ \\
\hline Vinogradovite & $\mathrm{Na}_{4} \mathrm{Ti}_{4}\left(\mathrm{Si}_{2} \mathrm{O}_{6}\right)_{2}\left[(\mathrm{Si}, \mathrm{Al})_{4} \mathrm{O}_{10}\right] \mathrm{O}_{4} \cdot\left(\mathrm{H}_{2} \mathrm{O}, \mathrm{Na}, \mathrm{K}\right)_{3}$ \\
\hline Vuonnemite & $\mathrm{Na}_{6} \mathrm{Na}_{2} \mathrm{Nb}_{2} \mathrm{Na}_{3} \mathrm{Ti}\left(\mathrm{Si}_{2} \mathrm{O}_{7}\right)_{2}\left(\mathrm{PO}_{4}\right)_{2} \mathrm{O}_{2}(\mathrm{OF})$ \\
\hline Vitusite-(Ce) & $\mathrm{Na}_{3} \mathrm{Ce}\left(\mathrm{PO}_{4}\right)_{2}$ \\
\hline
\end{tabular}

${ }^{1}$ according to the IMA (international mineralogical association) list; $\square$-vacancy. 

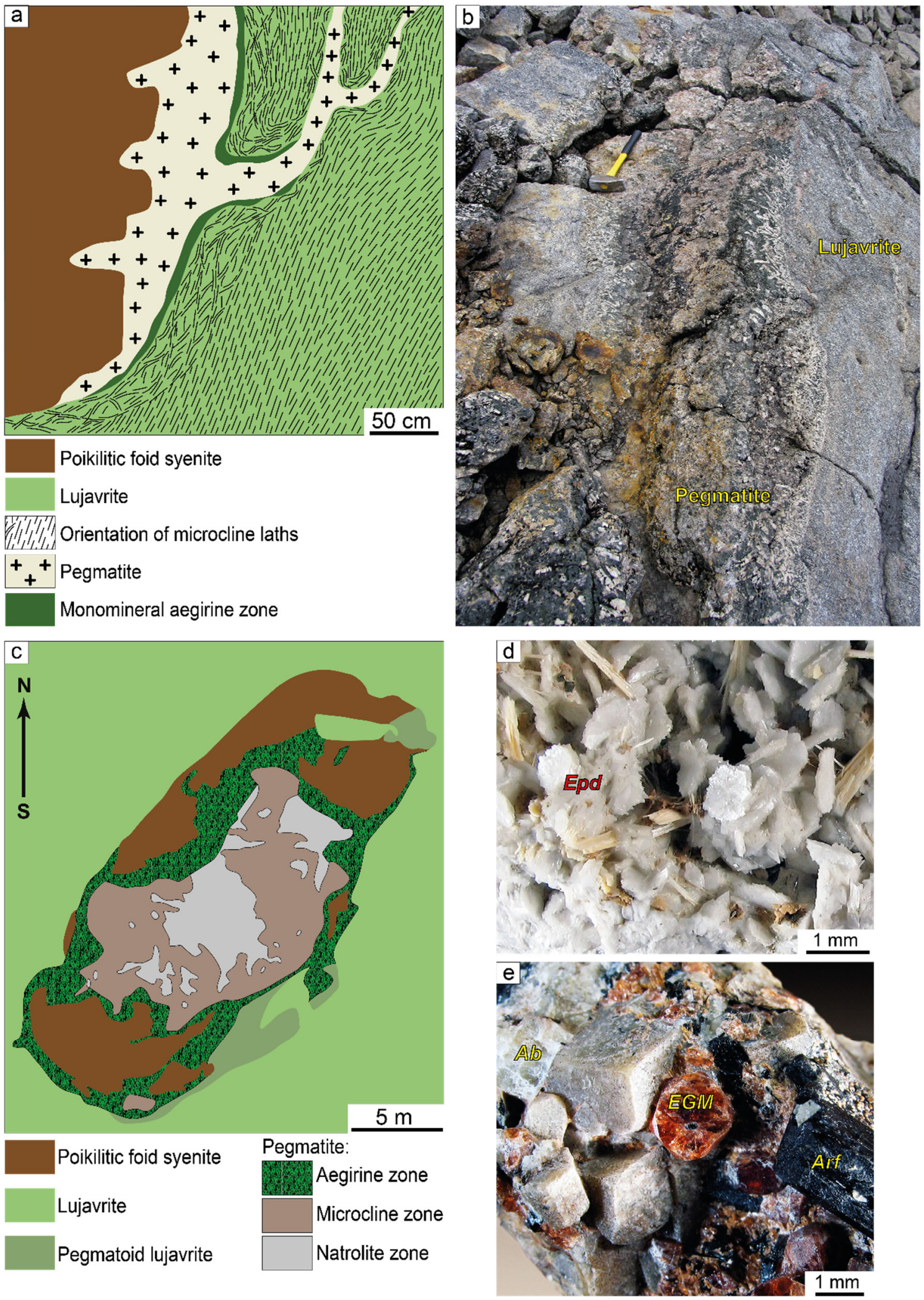

Figure 2. (a) Scheme of pegmatite apophysis in lujavrite, adapted from [27]. Lujavrite lacks a trachytoid texture near the contact. (b) Pegmatite apophysis in lujavrite on Sengischorr Mountain. Photo by Gregory Ivanyuk. (c) Scheme of the pegmatite No. 47 (Lepkhe-Nel'm Mountain), adapted from [28]. In this example, the volume of poikilitic foid syenite is small compared with the volume of pegmatite, but this ratio can vary greatly. (d) Epididymite (Epd) crystals from pegmatite No. 47. (e) Eudialyte (EGM), arfvedsonite (Arf), and albite (Ab) crystals pegmatite No. 47. Photo by Gregory Ivanyuk. 


\section{Materials and Methods}

We studied poikilitic rocks, the bodies of which are located in the Eudialyte complex of the Lovozero massif. Samples for the study were collected in two areas (Figure 1): Alluive Mountain (drill cores, sampling profile 1 in Figure 1) and Sengischorr Mountain (outcrops, sampling area 2 in Figure 1). Figure 3a shows a schematic cross-section of sampling profile 1 (see Figure 1), well locations, and sampling intervals. On the Sengischorr Mountain, samples were taken from six outcrops. One such outcrop and sampling points are shown in Figure 3b.
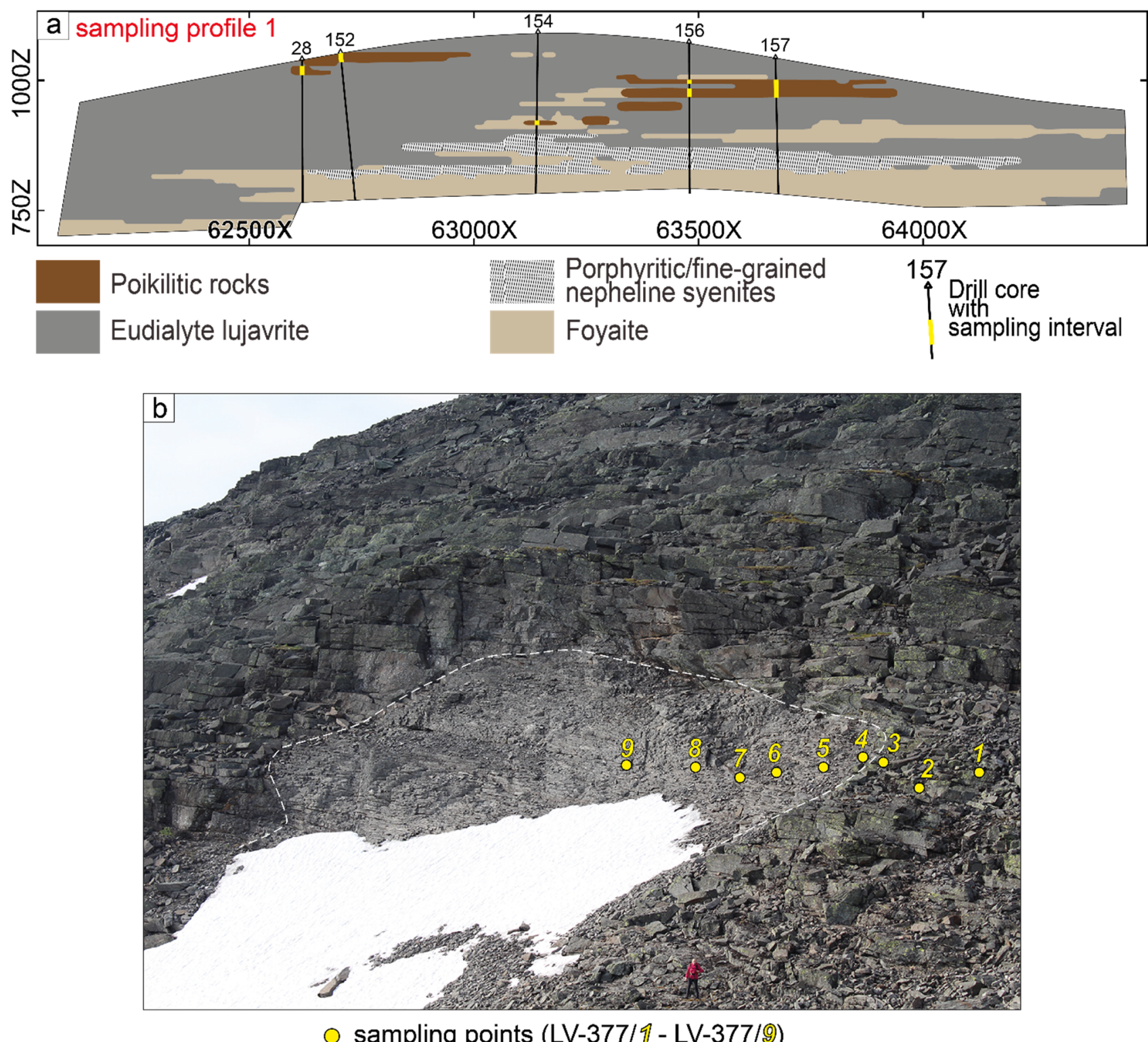

Figure 3. (a) Schematic cross section along sampling profile 1 [54]. Only those wells from which samples were used in this article are shown. The lenses of the poikilitic rocks are located near the foyaite or at the same level. (b) Outcrop (LV-377) of poikilitic rocks within sampling area 2. Poikilitic rocks form a lens-like body (outlined by a white dashed line) among eudialyte lujavrite.

The 36 thin polished sections were analyzed at the Geological Institute of the Kola Science Center of the Russian Academy of Sciences (GI KSC RAS, Apatity, Russia) using a scanning electron microscope LEO-1450 (Carl Zeiss Microscopy, Oberkochen, Germany) with the energy-dispersive system Quantax 200 to obtain BSE (back-scattered electron) 
images and pre-analyze all detected minerals. The chemical composition of minerals was analyzed with the Cameca MS-46 electron microprobe (Cameca, Gennevilliers, France) operating in the WDS-mode at $22 \mathrm{kV}$ with a beam diameter of $10 \mu \mathrm{m}$, beam current of 20-40 nA, and counting times of $20 \mathrm{~s}$ (for a peak) and 2-10 s (for background before and after the peak), with 5-10 counts for every element in each point. The analytical precision (reproducibility) of mineral analyses was $0.2-0.05 \mathrm{wt} \%$ ( 2 standard deviations) for the major element and approximately $0.01 \mathrm{wt} \%$ for impurities. The standards used, the detection limits, and the analytical accuracy values are given in Supplementary Table S1. The systematic errors were within the random errors.

Diagnostics of feldspathoids, as well as the study the structural state of the potassium feldspar, were carried out using X-ray diffraction (XRD). XRD measurements were taken with a DRON-2 diffractometer (Burevestnik, Saint-Peterburg, Russia) at the GI KSC RAS. The operating parameters were as follows: $\mathrm{CuK} \alpha$ radiation, $20 \mathrm{~mA}, 30 \mathrm{kV}$. XRD data were identified using the RRUFF Project database [55].

In situ laser ablation inductively coupled plasma mass spectrometer (LA-ICP-MS) analyses of $\mathrm{Li}$ in amphiboles were performed at the Institute of Geology Karelian Research Centre Russian Academy of Sciences (Petrozavodsk, Russia) using a mass spectrometer X-Series 2 (Thermo Fisher Scientific, Waltham, MA, USA) equipped with a $266 \mathrm{~nm}$ Nd-YAG laser (UP-266 Macro). NIST 640 was used as a secondary standard. The laser beam diameter at the sample surface was approximately $70 \mu \mathrm{m}$.

Major elements in rocks were determined by a wet chemical analysis at the GI KSC RAS. The accuracy limits of the wet chemical analysis are given in Supplementary Table S1. Statistical analyses were carried out using the STATISTICA 13 [56]. For the statistics, resulting values of the analyses below the limit of accuracy (see Supplementary Table S1) were considered ten times lower than the limit.

Factor analysis was used to detect patterns of changes in the chemical composition of rocks and minerals. It is a statistical method used to describe variability among observed, correlated variables in terms of a lower number of unobserved variables called factors [57]. This method allows us to describe an object comprehensively and, at the same time, compactly.

Mineral abbreviations mentioned in this article are shown in Table 3.

Table 3. Mineral abbreviations used in figures and text.

\begin{tabular}{|c|c|c|}
\hline Symbol & Mineral Name & Formula $^{1}$ \\
\hline $\mathrm{Ab}$ & Albite & $\mathrm{Na}\left(\mathrm{AlSi}_{3} \mathrm{O}_{8}\right)$ \\
\hline Aeg & Aegirine & $\mathrm{NaFeSi}_{2} \mathrm{O}_{6}$ \\
\hline Aeg-Au & Aegirine-augite & $(\mathrm{Ca}, \mathrm{Na})\left(\mathrm{Fe}^{3+}, \mathrm{Mg}, \mathrm{Fe}^{2+}\right) \mathrm{Si}_{2} \mathrm{O}_{6}$ \\
\hline Ap & Fluorapatite & $\mathrm{Ca}_{5}\left(\mathrm{PO}_{4}\right)_{3} \mathrm{~F}$ \\
\hline Arf & Arfvedsonite & $\mathrm{NaNa}_{2}\left(\mathrm{Fe}^{2+}{ }_{4} \mathrm{Fe}^{3+}\right) \mathrm{Si}_{8} \mathrm{O}_{22}(\mathrm{OH})_{2}$ \\
\hline Bdy & Baddeleyite & $\mathrm{ZrO}_{2}$ \\
\hline $\mathrm{Di}$ & Diopside & $\mathrm{CaMgSi}_{2} \mathrm{O}_{6}$ \\
\hline EGM & Eudialyte-group minerals & $\begin{array}{r}\mathrm{N}_{15} \mathrm{M1}_{6} \mathrm{M}_{3} \mathrm{M}_{3} \mathrm{M} 4 \mathrm{Z}_{3}\left[\mathrm{Si}{ }_{24} \mathrm{O}_{73}\right] \mathrm{O}^{\prime}{ }_{4} \mathrm{X}_{2} ; \mathrm{N}=\mathrm{Na}, \mathrm{Ca}, \mathrm{K}, \mathrm{Sr}, \mathrm{REE}, \mathrm{Ba}, \mathrm{Mn} \mathrm{H}_{3} \mathrm{O}^{+} ; \\
\mathrm{M} 1=\mathrm{Ca}, \mathrm{Mn}, \mathrm{REE}, \mathrm{Na}, \mathrm{Sr}, \mathrm{Fe} ; \mathrm{M} 2=\mathrm{Fe}, \mathrm{Mn}, \mathrm{Na}, \mathrm{Zr}, \mathrm{Ta}, \mathrm{Ti}, \mathrm{K}, \mathrm{Ba}, \mathrm{H}_{3} \mathrm{O}^{+} ; \mathrm{M} 3, \\
4=\mathrm{Si}, \mathrm{Nb}, \mathrm{Ti}, \mathrm{W}, \mathrm{Na} ; \mathrm{Z}=\mathrm{Zr}, \mathrm{Ti}, \mathrm{Nb} ; \mathrm{O}^{\prime}=\mathrm{O}, \mathrm{OH}^{-}, \mathrm{H}_{2} \mathrm{O} ; \mathrm{X}=\mathrm{H}_{2} \mathrm{O}, \mathrm{Cl}^{-}, \mathrm{F}^{-}, \mathrm{OH}^{-}, \\
\mathrm{CO}_{3}{ }^{2-}, \mathrm{SO}_{4}{ }^{2-}[58]\end{array}$ \\
\hline F-Ktp & Ferri-fluoro-katophorite & $\mathrm{Na}(\mathrm{NaCa})\left(\mathrm{Mg}_{4} \mathrm{Fe}^{3+}\right)\left(\mathrm{Si}_{7} \mathrm{Al}\right) \mathrm{O}_{22} \mathrm{~F}_{2}$ \\
\hline $\mathrm{Ilm}$ & Ilmenite & $\mathrm{Fe}^{2+} \mathrm{Ti}^{4+} \mathrm{O}_{3}$ \\
\hline Ktp & Ferri-katophorite & $\mathrm{Na}(\mathrm{NaCa})\left(\mathrm{Mg}_{4} \mathrm{Fe}^{3+}\right)\left(\mathrm{Si}_{7} \mathrm{Al}\right) \mathrm{O}_{22}(\mathrm{OH})_{2}$ \\
\hline Lmp & Lamprophyllite & 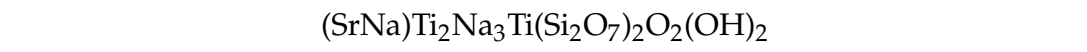 \\
\hline
\end{tabular}


Table 3. Cont

\begin{tabular}{|c|c|c|}
\hline Symbol & Mineral Name & Formula $^{1}$ \\
\hline Lop & Loparite-(Ce) & $(\mathrm{Na}, \mathrm{Ce}, \mathrm{Sr})(\mathrm{Ce}, \mathrm{Th})(\mathrm{Ti}, \mathrm{Nb})_{2} \mathrm{O}_{6}$ \\
\hline Lvn & Låvenite & $(\mathrm{Na}, \mathrm{Ca})_{4}\left(\mathrm{Mn}^{2+}, \mathrm{Fe}^{2+}\right)_{2}(\mathrm{Zr}, \mathrm{Ti}, \mathrm{Nb})_{2}\left(\mathrm{Si}_{2} \mathrm{O}_{7}\right)_{2}(\mathrm{O}, \mathrm{F})_{4}$ \\
\hline Mag & Magnetite & $\mathrm{Fe}^{2+} \mathrm{Fe}^{3+}{ }_{2} \mathrm{O}_{4}$ \\
\hline Mc & Microcline & $\mathrm{K}\left(\mathrm{AlSi}_{3} \mathrm{O}_{8}\right)$ \\
\hline Marf & Magnesio-arfvedsonite & $\mathrm{NaNa}_{2}\left(\mathrm{Mg}_{4} \mathrm{Fe}^{3+}\right) \mathrm{Si}_{8} \mathrm{O}_{22}(\mathrm{OH})_{2}$ \\
\hline $\mathrm{Nph}$ & Nepheline & $\mathrm{Na}_{3} \mathrm{~K}\left(\mathrm{Al}_{4} \mathrm{Si}_{4} \mathrm{O}_{16}\right)$ \\
\hline Ntr & Natrolite & $\mathrm{Na}_{2}\left(\mathrm{Si}_{3} \mathrm{Al}_{2}\right) \mathrm{O}_{10} \cdot 2 \mathrm{H}_{2} \mathrm{O}$ \\
\hline Or & Orthoclase & $\mathrm{K}\left(\mathrm{AlSi}_{3} \mathrm{O}_{8}\right)$ \\
\hline $\mathrm{Pcl}$ & Pyrochlore-group minerals & $\begin{array}{c}\mathbf{A}_{2-\mathbf{m}} \mathbf{B}_{2} \mathbf{X}_{6-w} \mathbf{Y}_{1-\mathbf{n}} ; \mathrm{A}=\mathrm{Na}, \mathrm{Ca}, \mathrm{Sr}, \mathrm{Pb}, \mathrm{Sn}, \mathrm{Sb}, \mathrm{Y}, \square ; \\
\mathrm{B}=\mathrm{Ta}, \mathrm{Nb}, \mathrm{Ti}, \mathrm{Sb}, \mathrm{W} ; \mathrm{X}=\mathrm{O} ; \mathrm{Y}=\square, \mathrm{H}_{2} \mathrm{O}, \mathrm{OH}^{-}, \mathrm{O}, \mathrm{F}[59]\end{array}$ \\
\hline Phl & Phlogopite & $\mathrm{KMg}_{3}\left(\mathrm{AlSi}_{3} \mathrm{O}_{10}\right)(\mathrm{OH})_{2}$ \\
\hline Pkl & Parakeldyshite & $\mathrm{Na}_{2} \mathrm{ZrSi}_{2} \mathrm{O}_{7}$ \\
\hline Po & Pyrrhotite & $\mathrm{Fe}_{7} \mathrm{~S}_{8}$ \\
\hline Rct & Richterite & $\mathrm{Na}(\mathrm{NaCa}) \mathrm{Mg}_{5} \mathrm{Si}_{8} \mathrm{O}_{22}(\mathrm{OH})_{2}$ \\
\hline Rnk & Rinkite-(Ce) & $\left(\mathrm{Ca}_{3} \mathrm{REE}\right) \mathrm{Na}(\mathrm{NaCa}) \mathrm{Ti}\left(\mathrm{Si}_{2} \mathrm{O}_{7}\right)_{2}(\mathrm{OF}) \mathrm{F}_{2}$ \\
\hline Sdl & Sodalite & $\mathrm{Na}_{4}\left(\mathrm{Si}_{3} \mathrm{Al}_{3}\right) \mathrm{O}_{12} \mathrm{Cl}$ \\
\hline Sph & Sphalerite & $\mathrm{ZnS}$ \\
\hline Tau & Tausonite & $\mathrm{SrTiO}_{3}$ \\
\hline Ttn & Titanite & $\mathrm{CaTi}\left(\mathrm{SiO}_{4}\right) \mathrm{O}$ \\
\hline Ulv & Ulvöspinel & $\mathrm{Fe}^{2+}{ }_{2} \mathrm{TiO}_{4}$ \\
\hline Vish & Vishnevite & $\mathrm{Na}_{8}\left(\mathrm{Al}_{6} \mathrm{Si}_{6}\right) \mathrm{O}_{24}\left(\mathrm{SO}_{4}\right) \cdot 2 \mathrm{H}_{2} \mathrm{O}$ \\
\hline Wlr & Wöhlerite & $\mathrm{Na}_{2} \mathrm{Ca}_{4} \mathrm{Zr}(\mathrm{Nb}, \mathrm{Ti})\left(\mathrm{Si}_{2} \mathrm{O}_{7}\right)_{2}(\mathrm{O}, \mathrm{F})_{4}$ \\
\hline Zrn & Zircon & $\mathrm{Zr}\left(\mathrm{SiO}_{4}\right)$ \\
\hline
\end{tabular}

${ }^{1}$ according to the IMA (international mineralogical association) list, except for eudialyte- and pyrochlore-group minerals; $\square$-vacancy.

\section{Results}

\subsection{Petrography}

Uneven-grained nepheline syenite and poikilitic foid syenite are leucocratic coarsegrained massive rocks with a metasomatic texture. These rocks are connected by gradual transitions but differ in the intensity of metasomatic alterations. Rock-forming minerals are alkaline feldspars (microcline, orthoclase), albite, feldspathoids (vishnevite, sodalite, nepheline), phlogopite, sodium-calcium and sodium amphiboles, clinopyroxenes (diopside, aegirine-augite, aegirine). Accessory minerals are titanite, fluorapatite, loparite-(Ce), EGM, lamprophyllite, ilmenite, magnetite, parakeldyshite, zircon, baddeleyite, tausonite, pyrrhotite, sphalerite.

Based on petrographic observations, a sequence of metasomatic events could be determined. In uneven-grained nepheline syenite, the intensity of metasomatism is relatively low. This rock contains numerous relics of microcline, which were replaced by albite along the grain edges and along fractures (Figure 4a). Albitization was followed by intense nephelinization. Indeed, relics of microcline and albite are often present in the fine-grained mass of nepheline. We assume that large crystals (up to $3 \mathrm{~cm}$ across, Figure $4 \mathrm{~b}$ ) of nepheline are formed as a result of recrystallization (or coarsening [60]) of small grains of this mineral. 

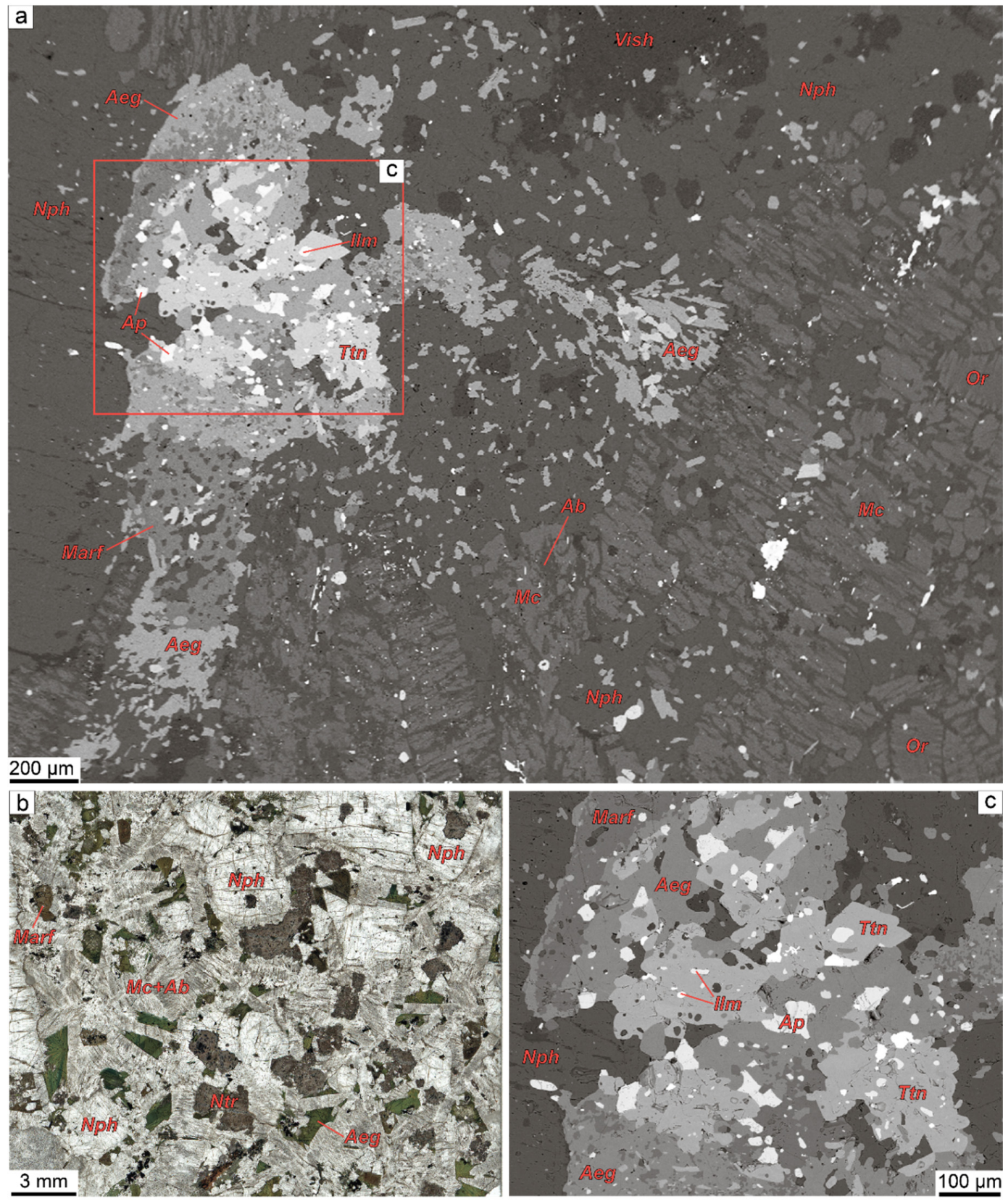

Figure 4. Back-scattered electron (BSE) images (a,c) and a photo in transmitted light (b) showing the textural relations and mineral paragenesis in uneven-grained nepheline syenite. (a) Resorption of microcline by albite and nepheline. Segregation consisting of magnesio-arfvedsonite, aegirine, ilmenite, titanite, and fluorapatite is located among nepheline. On the left, there is a fragment of a large nepheline crystal (Sample LV-156-66). (b) Characteristic texture with large euhedral nepheline crystals and resorbed microcline laths (Sample LV-157-54). (c) Characteristic association of mafic minerals. Magnesio-arfvedsonite is replaced by aegirine (Sample LV-156-66).

Mafic minerals form polymineral segregations in the fine-grained nepheline mass (Figure 4a,c). The main mafic minerals are clinopyroxenes and amphiboles, which are usually arranged in an orderly manner: calcium end-members (e.g., diopside) are first surrounded by a rim of a calcium-sodium mineral (e.g., aegirine-augite) and outside, there is a rim of a sodium end-member (e.g., aegirine, Figure 5a). Other examples are as follows (from core to rim): magnesio-arfvedsonite-aegirine (Figures $4 \mathrm{a}$ and 5b), diopside-ferrikatophorite-aegirine, diopside-richterite-aegirine. In spatial association with clinopyroxenes and amphiboles, there are ilmenite grains (sometimes with magnetite lamellae) surrounded by a titanite rim (Figure 5b), wedge-shaped crystals of titanite, rounded 
fluorapatite and magnetite grains, cube crystals of loparite-(Ce) and pyrochlore group minerals, zircon grains with small inclusions of baddeleyite. Moreover, small crystals or rounded grains of loparite-(Ce), zircon, and pyrochlore-group minerals are often found within ilmenite grains (Figure 5c). Phlogopite forms lamellar crystals with numerous inclusions of nepheline, titanite, ilmenite, fluorapatite, loparite-(Ce) and is surrounded by a ferri-katophorite rim (Figure 5d). Parakeldyshite forms rounded grains with numerous inclusions of loparite-(Ce) and is surrounded by an EGM rim (Figure 5e).
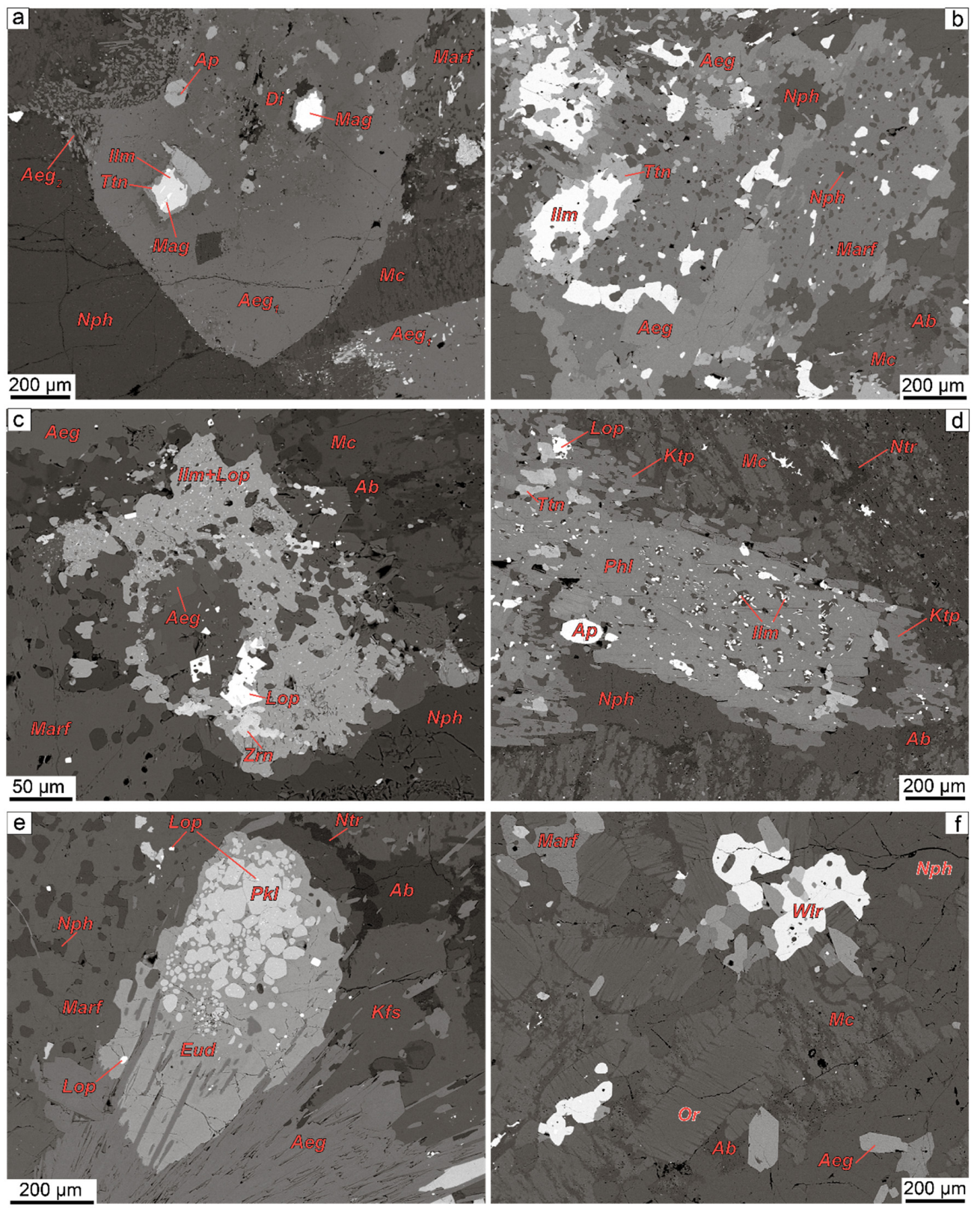

Figure 5. BSE images showing the textural relations and mineral paragenesis in uneven-grained nepheline syenite: (a) symplectite intergrowths of nepheline and magnesio-arfvedsonite are surrounded by aegirine rims, and ilmenite is replaced by titanite (Sample LV-156-118); (b) inclusions of loparite-(Ce) and zircon in ilmenite (Sample LV-157-83); (c) phlogopite contains inclusions of ilmenite, fluorapatite, and titanite and is surrounded by a ferri-katophorite rim (Sample LV-157-83); (d) relict diopside

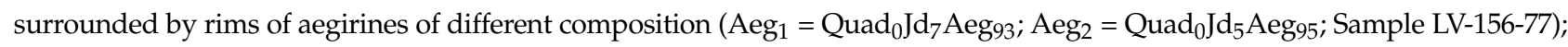
(e) parakeldyshite grains with inclusions of loparite-(Ce), surrounded by an EGM rim (Sample LV-156-108); (f) recrystallization of feldspar. Microcline is intensively resorbed by nepheline, and orthoclase laths are crystallized (Sample LV-372). 
In uneven-grained nepheline syenite, nepheline is replaced by vishnevite (Figure 4a), and feldspar is recrystallized with the formation of small crystals of orthoclase (Figures $4 \mathrm{a}$ and 5f). Some orthoclase crystals contain single poikilitic inclusions of nepheline and/or vishnevite. However, the amount of vishnevite in this rock is small, and poikilitic orthoclase is rare.

Poikilitic foid syenite is composed of large poikilitic orthoclase crystals with vishnevite inclusions (Figure 6a). In this rock, not only nepheline (Figure 6b) but also orthoclase (Figure 6c) is intensively replaced by vishnevite. Poikilitic foid syenite was potentially formed as a result of further development of orthoclasization and vishnevitization processes, the first signs of which were observed in uneven-grained nepheline syenite. The association of mafic minerals in poikilitic foid syenite is similar to that in uneven-grained nepheline syenites. Tabular crystals of phlogopite contain titanite inclusions and are surrounded by a rim of small crystals of aegirine (Figure $6 \mathrm{~d}, \mathrm{f}$ ). Diopside grains are intensively resorbed by ferri-kataphorite, richterite, and aegirine (Figure 6e). Titanite forms irregular grains, wedge-shaped crystals, and rims around magnetite and ilmenite (Figure 6f). Magnetite contains ilmenite or ulvöspinel lamellae. Fluorapatite, zircon, tausonite, rinkite(Ce), wöhlerite, låvenite, EGM, pyrrhotite, and sphalerite are characteristic for accessory minerals.

Thus, in the process of the formation of poikilitic rocks, there are two main stages: albitization + nephelinization (as a result, uneven-grained nepheline syenite was formed) and orthoclasization + vishnevitization (at this stage, poikilitic foid syenite was formed).

\subsection{Contact between Poikilitic Rocks and Eudialyte Lujavrite}

We studied the contact between poikilitic foid syenite and eudialyte lujavrite using samples from profile LV-377 (see Figure 3b). The following zones were distinguished:

- $\quad-20-0 \mathrm{~cm}$ from contact: Pegmatite-like zone consisting of large crystals of microcline and monomineral lenses of aegirine.

- $\quad$ 0-40 cm from contact (Figure 7a,b): Leucocratic lujavrite. The microcline is recrystallized with the formation of large (up to $3 \mathrm{~cm}$ across) rectangular crystals. At the same time, non-recrystallized microcline laths and a trachytoid texture typical of lujavrite are preserved. The rocks are intensively natrolyzed.

- $\quad 40-60 \mathrm{~cm}$ from contact (Figure 7c,d): Sodalite-enriched eudialyte lujavrite.

- $\quad>60 \mathrm{~cm}$ from contact: Eudialyte lujavrite.

\subsection{Rock Chemistry}

The chemical compositions of uneven-grained nepheline syenite and poikilitic foid syenite vary widely (Supplementary Table S2). According to the results of factor analysis (Figure 8), uneven-grained nepheline syenite is relatively enriched in $\mathrm{Si}$ and $\mathrm{K}$, as well as in $\mathrm{Zr}, \mathrm{Ti}, \mathrm{Mn}, \mathrm{Fe}^{3+}, \mathrm{Li}$, while poikilitic syenite is enriched in $\mathrm{Na}$ and $\mathrm{Al}$, as well as in $\mathrm{Ca}, \mathrm{Sr}$, $\mathrm{P}$, and volatiles $\left(\mathrm{S}, \mathrm{Cl}, \mathrm{H}_{2} \mathrm{O}\right)$.

Using factor analysis, we compared the chemical compositions of the poikilitic rocks with those of the main rocks of the massif [54]. First, it should be noted that the compositions of lujavrite and foyaite from the Eudialyte complex and similar rocks from the Layered complex are similar. Lujavrite is enriched in ferrous and ferric iron, calcium, magnesium (included in compositions of rock-forming Na-clinopyroxenes and Na-amphiboles), titanium, fluorine (included in the composition of lamprophyllite), zirconium, manganese, and chlorine (included in the composition of EGM). With the transition from lujavrite to foyaite, the content of above-mentioned elements decreases and the amount of potassium (i.e., feldspar) increases. The main rock-forming mineral of the Layered complex urtite is nepheline, and the characterizing accessory minerals are various silicophosphates and phosphates, mainly fluorapatite [61]. Therefore, urtite is characterized by enrichment in $\mathrm{Al}, \mathrm{Na}, \mathrm{Ca}$, and P. There is no urtite in the Eudialyte complex (Table 2), but its chemical composition corresponds to poikilitic rocks. The difference between urtite and poikilitic rocks is that the latter contain more sulfur and strontium. 

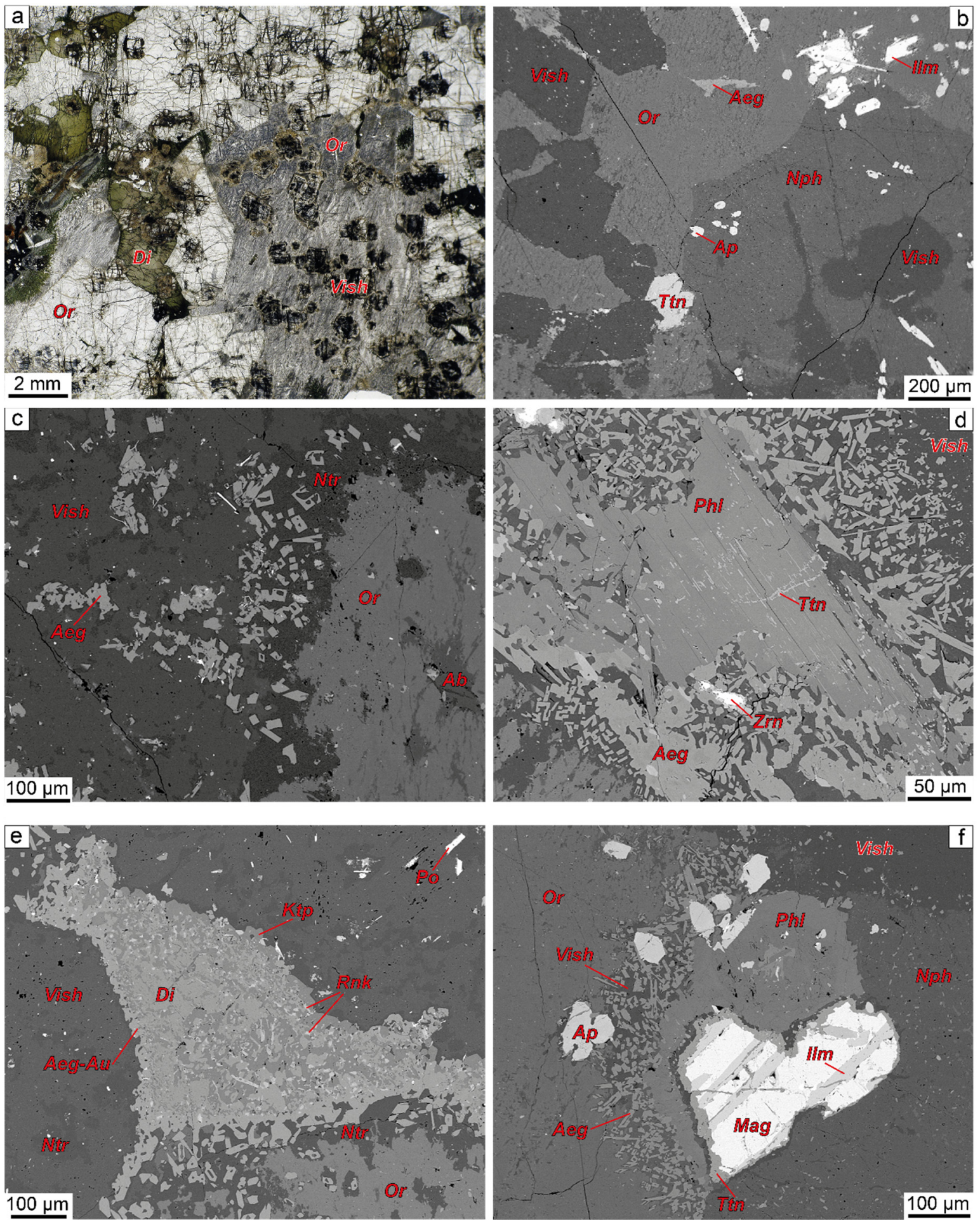

Figure 6. Photograph in transmitted light (a) and BSE images $(\mathbf{b}-\mathbf{f})$ showing the textural relations and mineral paragenesis in poikilitic foid syenite: (a) large poikilitic orthoclase crystals with inclusions of vishnevite is the characteristic texture of poikilitic foid syenite (Sample LV-381); (b) fragment of a large grain of orthoclase with inclusions of vishnevite and nepheline, nepheline is replaced by vishnevite (Sample LV-378-2), (c) replacement of orthoclase with natrolite and vishnevite (Sample LV-377-7); (d) platy crystal of phlogopite with inclusions of titanite (Sample LV-378-2); (e) relicts of diopside resorbed by ferri-katophorite and aegirine (Sample LV-377-8); (f) aegirine rim around phlogopite plates and titanite rim surrounding magnetite grain with ilmenite lamellae (Sample LV-378-2). 

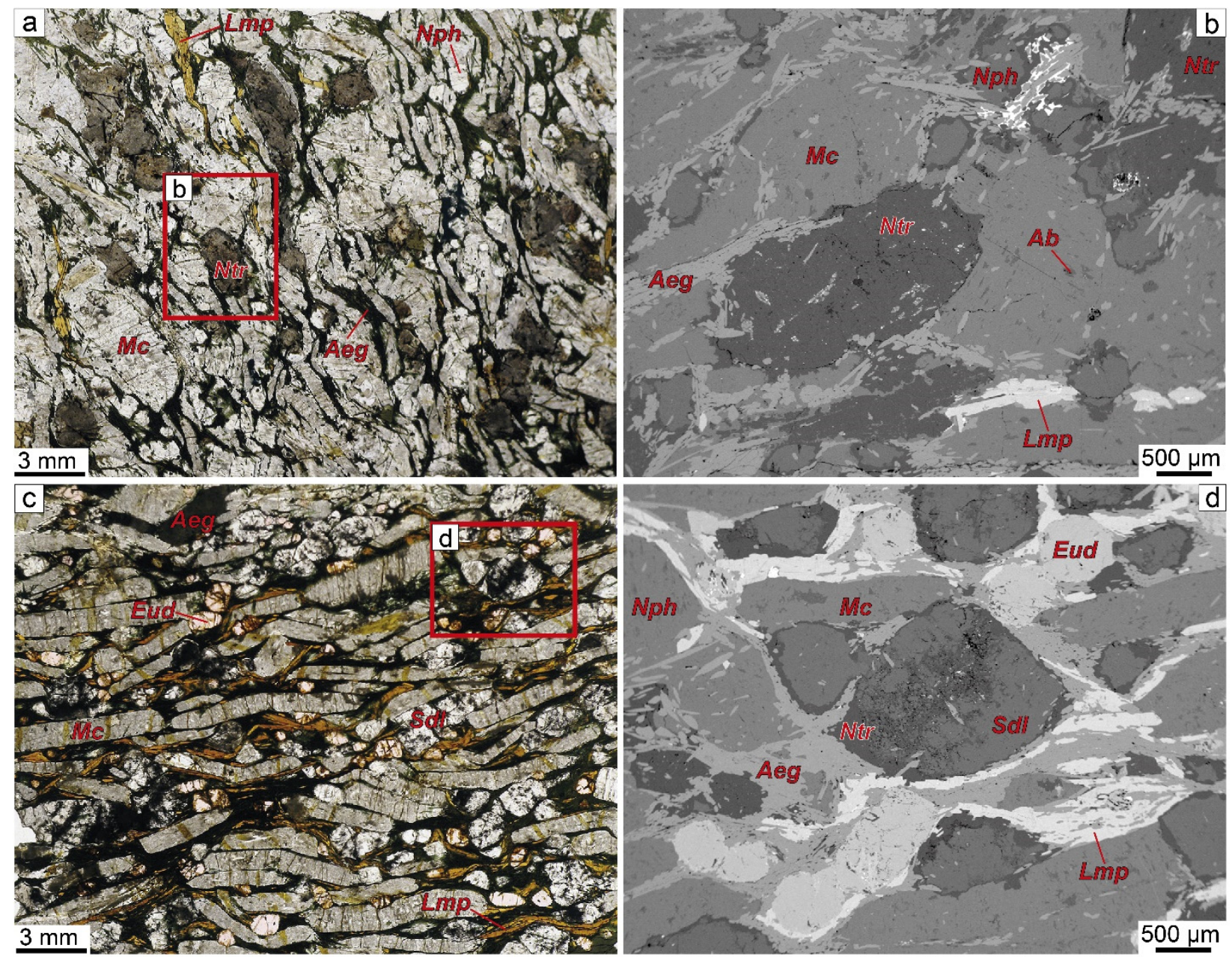

Figure 7. Photographs in transmitted light $(\mathbf{a}, \mathbf{c})$ and BSE images $(\mathbf{b}, \mathbf{d})$ showing the textural relations and mineral paragenesis in lujavrite near the contact with poikilitic rocks. (a) Leucocratic lujavrite $(20 \mathrm{~cm}$ from contact with poikilitic foid syenite, sample LV-377-3). Both large rectangular microcline crystals (supposedly, the result of recrystallization) and microcline laths are present. (b) Detail of Figure 7a (red rectangle). Intensive natrolitization of the rock is observed. (c) Eudialyte lujavrite enriched in sodalite (40 cm from contact with poikilitic foid syenite, sample LV-377-2). The sodalite content is $35 \mathrm{modal} \%$.

(d) Detail of Figure 7c (red rectangle). Sodalite is intensively replaced by natrolite.

In Figure 9, the points corresponding to the chemical compositions of the samples from the LV-377 profile are separately highlighted (see Figures $3 \mathrm{~b}$ and 7). Closer to the contact with poikilitic rocks, the content of $\mathrm{Ca}, \mathrm{Mg}, \mathrm{Fe}, \mathrm{Ti}, \mathrm{Zr}, \mathrm{Mn}, \mathrm{F}$, and $\mathrm{Cl}$ (main components of mafic minerals) in lujavrite decreases, while the concentration of potassium (i.e., feldspar) increases.

\subsection{Mineral Chemistry of Poikilitic Rocks}

\subsubsection{Alkali Feldspars}

The composition of relict microcline grains varies from $\mathrm{Or}_{98} \mathrm{Ab}_{2}$ to $\mathrm{Or}_{74} \mathrm{Ab}_{24} \mathrm{For}_{2}$ (where Or-orthoclase, $\mathrm{Ab}$-albite, For-ferriorthoclase $\mathrm{KFe}^{3+} \mathrm{Si}_{3} \mathrm{O}_{8}$ ). The composition of orthoclase varies more widely because the perthite content in them is quite different. The composition of homogeneous (without perthite) crystals is $\mathrm{Or}_{24-58} \mathrm{Ab}_{71-41} \mathrm{For}_{0-2}$. If the proportion of perthites is 3-15 vol\%, then the feldspar composition is $\mathrm{Or}_{58-67} \mathrm{Ab}_{42-33}$ For $_{0-2}$. An increase in the perthite volume (up to $38 \mathrm{vol} \%$ ) leads to a decrease in Na content in the matrix (up to $\mathrm{Or}_{98} \mathrm{Ab}_{2}$ ). Sometimes, within the same grain, there are separated areas of homogeneous and perthite-bearing potassium feldspar. Representative chemical analyses of alkali feldspars are in Supplementary Table S3. 


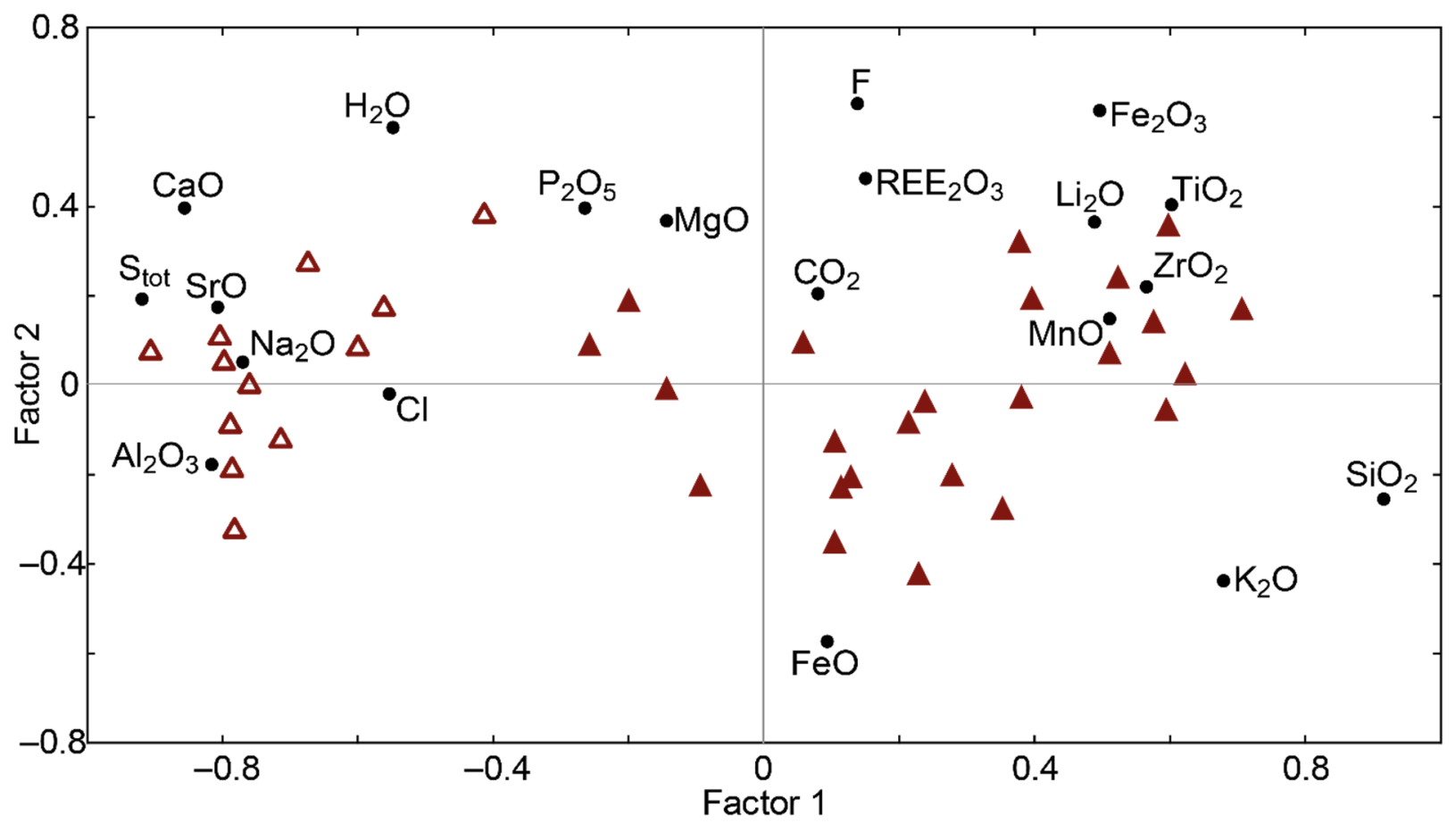

uneven-grained
nepheline syenite

$\Delta$ poikilitic foid syenite

\begin{tabular}{|c|c|c|c|c|c|}
\hline Var. & Factor 1 & Factor 2 & Var. & Factor 1 & Factor 2 \\
\hline $\mathrm{SiO}_{2}$ & 0.914 & -0.256 & $\mathrm{Na}_{2} \mathrm{O}$ & -0.775 & 0.051 \\
\hline $\mathrm{TiO}_{2}$ & 0.600 & 0.404 & $\mathrm{~K}_{2} \mathrm{O}$ & 0.675 & -0.427 \\
\hline $\mathrm{ZrO}_{2}$ & 0.565 & 0.214 & $\mathrm{Li}_{2} \mathrm{O}$ & 0.471 & 0.372 \\
\hline $\mathrm{Al}_{2} \mathrm{O}_{3}$ & -0.816 & -0.178 & $\mathrm{P}_{2} \mathrm{O}_{5}$ & -0.271 & 0.399 \\
\hline $\mathrm{Fe}_{2} \mathrm{O}_{3}$ & 0.495 & 0.621 & $\mathrm{H}_{2} \mathrm{O}$ & 50 & 0.572 \\
\hline $\mathrm{REE}_{2} \mathrm{O}_{3}$ & 0.1 & 0.46 & $F$ & & 0.632 \\
\hline $\mathrm{FeO}$ & & & $\mathrm{Cl}$ & 53 & -0.022 \\
\hline $\mathrm{MnO}$ & 0.515 & 0.152 & $\mathrm{CO}_{2}$ & 0.0 & 0.209 \\
\hline $\mathrm{MgO}$ & -0.140 & 0.369 & $S_{\text {tot }}$ & -0.915 & 0.193 \\
\hline $\mathrm{CaO}$ & -0.854 & 0.399 & Expl.var. & 6.710 & 2.519 \\
\hline $\mathrm{SrO}$ & -0.814 & 0.171 & Prp.totl & 0.373 & 0.140 \\
\hline
\end{tabular}

Figure 8. Results of factor analyses of data on the chemical composition of uneven-grained nepheline syenite and poikilitic foid syenite. Var.-variables; Expl.var.—explained variance; Prp.totl—proportion of total variance. Factor loadings > $0.6 \mid$ are shown in bold.

\subsubsection{Nepheline}

In the igneous rocks of the Lovozero (and Khibiny) massifs, nepheline is represented by two morphological types [62,63]. Nepheline-I occurs as euhedral crystals with numerous small inclusions of aegirine and microcline, and nepheline-II forms anhedral grains without inclusions. Nepheline-II is enriched in iron, which, as it was found in [54], is included in nepheline crystal structure according to the following scheme:

$$
\square_{\mathrm{B}}+\left(\mathrm{Si}^{4+}+\mathrm{Fe}^{3+}\right)_{\mathrm{T}} \leftrightarrows \mathrm{K}_{\mathrm{B}}^{+}+2 \mathrm{Al}^{3+} \mathrm{T}
$$

( $\square$-vacancy), if the composition of nepheline is expressed by the formula $\mathrm{A}_{4} \mathrm{~B}_{4} \mathrm{~T}_{8} \mathrm{O}_{16}$. 


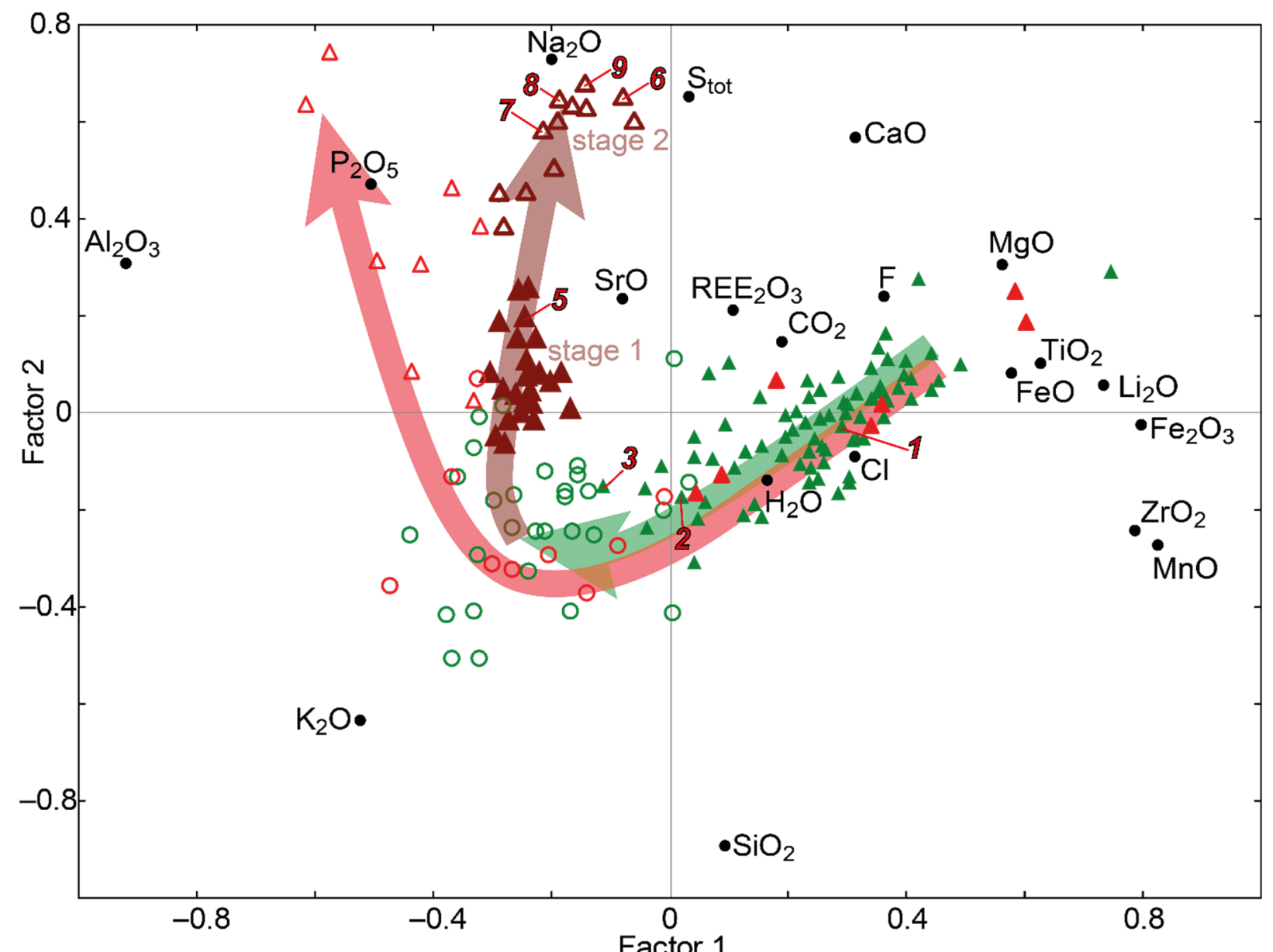

Layered complex:
$\Delta$ lujavrite
0 foyaite
$\triangle$ urtite
magmatic
differentiation

\section{Eudialyte complex:}

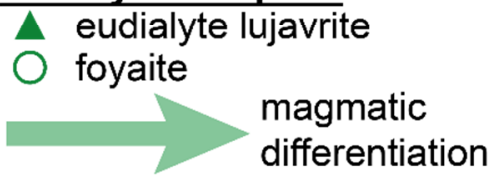

\begin{tabular}{|l|c|c|l|c|c|}
\hline \multicolumn{1}{|c|}{ Var. } & Factor 1 & Factor 2 & \multicolumn{1}{c|}{ Var. } & Factor 1 & Factor 2 \\
\hline $\mathrm{SiO}_{2}$ & 0.095 & $-\mathbf{0 . 8 9 1}$ & $\mathrm{Na}_{2} \mathrm{O}$ & -0.200 & $\mathbf{0 . 7 3 3}$ \\
\hline $\mathrm{TiO}_{2}$ & $\mathbf{0 . 6 2 5}$ & 0.103 & $\mathrm{~K}_{2} \mathrm{O}$ & -0.522 & $\mathbf{- 0 . 6 3 9}$ \\
\hline $\mathrm{ZrO}_{2}$ & $\mathbf{0 . 7 8 8}$ & -0.241 & $\mathrm{Li}_{2} \mathrm{O}$ & $\mathbf{0 . 7 3 2}$ & 0.054 \\
\hline $\mathrm{Al}_{2} \mathrm{O}_{3}$ & $-\mathbf{0 . 9 2 1}$ & 0.303 & $\mathrm{P}_{2} \mathrm{O}_{5}$ & -0.505 & 0.474 \\
\hline $\mathrm{Fe}_{2} \mathrm{O}_{3}$ & $\mathbf{0 . 7 9 8}$ & -0.016 & $\mathrm{H}_{2} \mathrm{O}$ & 0.162 & -0.137 \\
\hline $\mathrm{REE}_{2} \mathrm{O}_{3}$ & 0.112 & 0.210 & $\mathrm{~F}$ & 0.366 & 0.241 \\
\hline $\mathrm{FeO}$ & 0.578 & 0.087 & $\mathrm{Cl}$ & 0.316 & -0.089 \\
\hline $\mathrm{MnO}$ & $\mathbf{0 . 8 2 1}$ & -0.271 & $\mathrm{CO}_{2}$ & 0.188 & 0.140 \\
\hline $\mathrm{MgO}$ & 0.565 & 0.300 & $\mathrm{~S}_{\text {tot }}$ & 0.035 & $\mathbf{0 . 6 5 2}$ \\
\hline $\mathrm{CaO}$ & 0.312 & 0.561 & Expl.var. & 4.803 & 3.195 \\
\hline $\mathrm{SrO}$ & -0.079 & 0.233 & Prp.totl & 0.267 & 0.177 \\
\hline
\end{tabular}

\section{Poikilitic complex:}

stage 1 uneven-grained nepheline syenite metasomatic alteration

$\Delta$ poikilitic foid syenite

Figure 9. Results of factor analyses of data on the chemical composition of rocks of the Eudialyte [54], Layered, and poikilitic complexes. Points 1-3 correspond to eudialyte lujavrite near the contact of poikilitic foid syenite (see Figures $3 \mathrm{~b}$ and 7); points 5-9 correspond to poikilitic rocks (see Figure 3b); the point corresponding to sample 4 is absent because this sample is a pegmatoid zone at the contact of poikilitic syenite and lujavrite with a very variable modal composition. Var.- variables; Expl.var.-explained variance; Prp.totl-proportion of total variance. Factor loadings > $|0.6|$ are shown in bold. 
Only nepheline-II (without inclusions) was found in poikilitic rocks. Representative chemical analyses are presented in Supplementary Table S4. Trivalent iron (up to $0.14 \mathrm{Fe}^{3+} p f u$ ) enters in nepheline from these rocks according to the above-mentioned substitution scheme, because there is a negative correlation between $\left(\mathrm{Si}+\mathrm{Fe}^{3+}\right)$ apfu and $\mathrm{Al} p f u$ (Figure 10a) as well as a positive correlation Al pfu vs. K pfu (Figure 10b). This substitution does not allow for using the nepheline composition for temperature determination [64]. Differences in the composition of nepheline from uneven-grained nepheline syenite and poikilitic foid syenite were not found.

\subsubsection{Vishnevite}

Representative chemical analyses of vishnevite are given in Supplementary Table S5. The sums of oxides in all chemical analyses of vishnevite are very low (mean $92.5 \mathrm{wt} \%$ ). This could be due to the presence of water or $\mathrm{C}_{3}{ }^{2-}$ group. According to Semenov [28], vishnevite from the Lovozero massif does not contain carbonate groups. Although we did not make direct measurements of $\mathrm{CO}_{2}$ in the studied samples, the calculation of the charge balance showed a lack of positive charges and not negative ones (associated with the presence of carbonate groups). Supposedly, the lack of the sum in the composition of vishnevite corresponds to the water content, and not only in the form of $\mathrm{H}_{2} \mathrm{O}$ but also in the form of OH-groups. OH-groups could be included in vishnevite according to the scheme $\mathrm{Na}^{+}+\mathrm{O}^{2-} \rightarrow\left(\square, \mathrm{H}_{2} \mathrm{O}\right)^{0}+(\mathrm{OH})^{-}$, i.e., vishnevite in poikilitic rocks is hydrated. Indeed, the studied samples are characterized by a low content of sodium (mean $7.52 \mathrm{apfu}$ ) as well as potassium (mean $0.11 \mathrm{apfu}$ ) and calcium (mean $0.02 \mathrm{apfu}$ ). The Al/Si ratio in vishnevite from uneven-grained nepheline syenite is lower (mean 0.89) than the one from poikilitic foid syenite (mean 0.94 ).
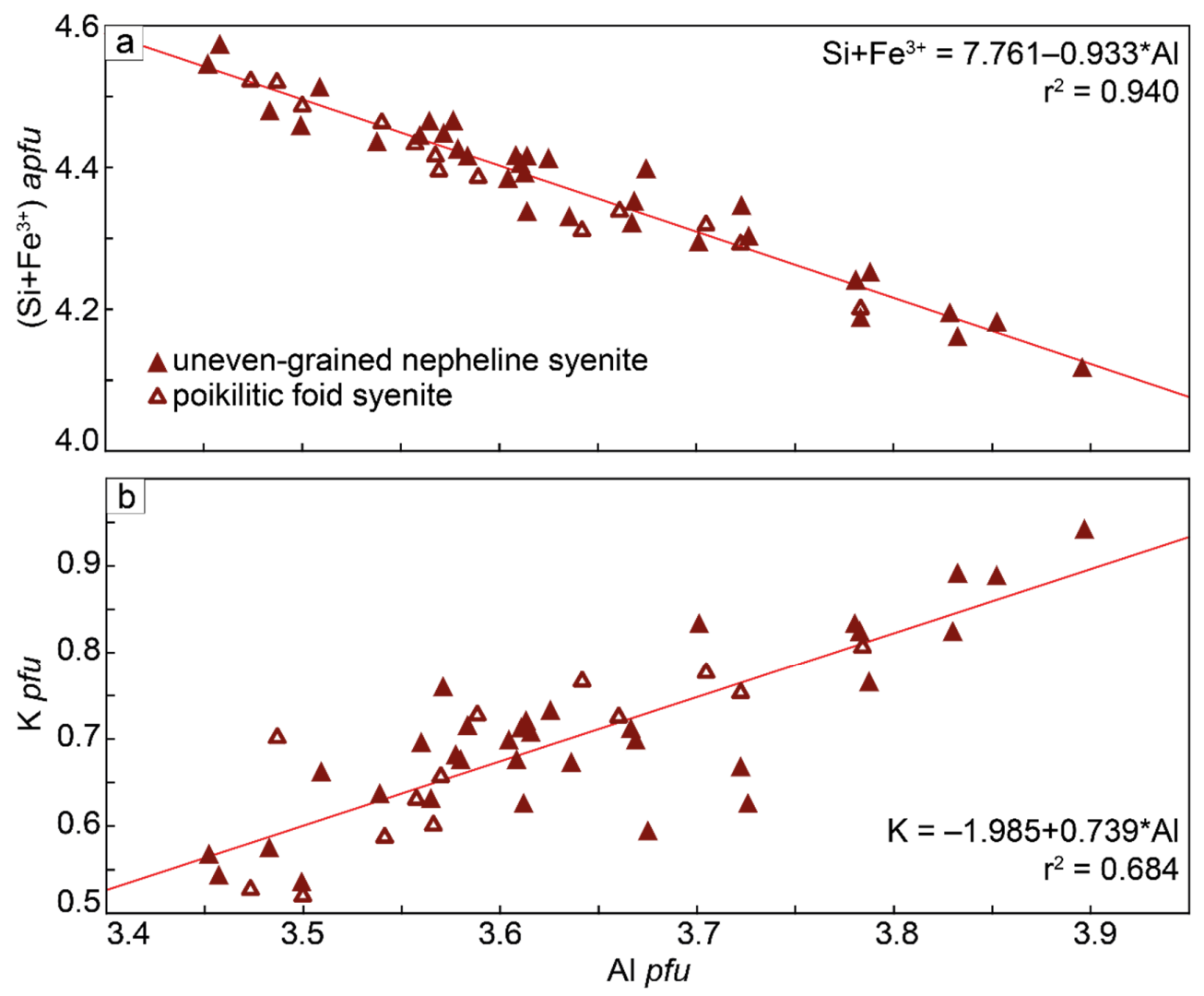

Figure 10. (a) Binary diagram showing the summary concentration $\left(\mathrm{Si}+\mathrm{Fe}^{3+}\right)$ in nepheline from poikilitic rocks as function of $\mathrm{Al}$ content; (b) binary diagram showing the $\mathrm{K}$ concentration in nepheline from poikilitic rocks as function of $\mathrm{Al}$ content. 


\subsubsection{Amphiboles}

Representative chemical analyses of amphiboles are shown in Supplementary Table S6. The amphibole-group mineral formulae were calculated based on $\mathrm{O}+\mathrm{OH}+\mathrm{F}=24$ atoms per formula unit and $\mathrm{OH}=2-2 \mathrm{Ti}$. The formula calculation was performed following the IMA 2012 recommendations [65] using the Excel spreadsheet of Locock [66]. This calculation resulted in slightly underoccupied C-cites and over-occupied A-sites (for the general formula $\mathrm{AB}_{2} \mathrm{C}_{5} \mathrm{~T}_{8} \mathrm{O}_{22} \mathrm{~W}_{2}$ ), which may be explained by significant Li content [67]. Indeed, the lithium content in amphiboles reaches 0.12 apfu (Table S6).

Unlike other rocks of the Eudialyte complex, where amphiboles are represented only by sodium end-members (magnesio-arfvedsonite and, less often, arfvedsonite), a wide variety of amphiboles was found in poikilitic rocks. Magnesio-arfvedsonite, usually forming symplectite intergrowths with nepheline, is typical of uneven-grained nepheline syenite (Figures $4 \mathrm{a}$ and 5a). Poikilitic foid syenite typically contain sodium-calcium amphiboles, such as ferri-katophorite, ferri-fluoro-katophorite, and richterite. Indeed, amphiboles from poikilitic rocks are characterized by higher concentrations of aluminum and calcium compared with amphiboles from other rocks of the Eudialyte complex (Figure 11a,b). In addition to lithium, titanium (max $0.30 \mathrm{apfu}$ in poikilitic foid syenite) and zirconium (max 0.02 apfu in uneven-grained nepheline syenite) are typical impurities in amphiboles.
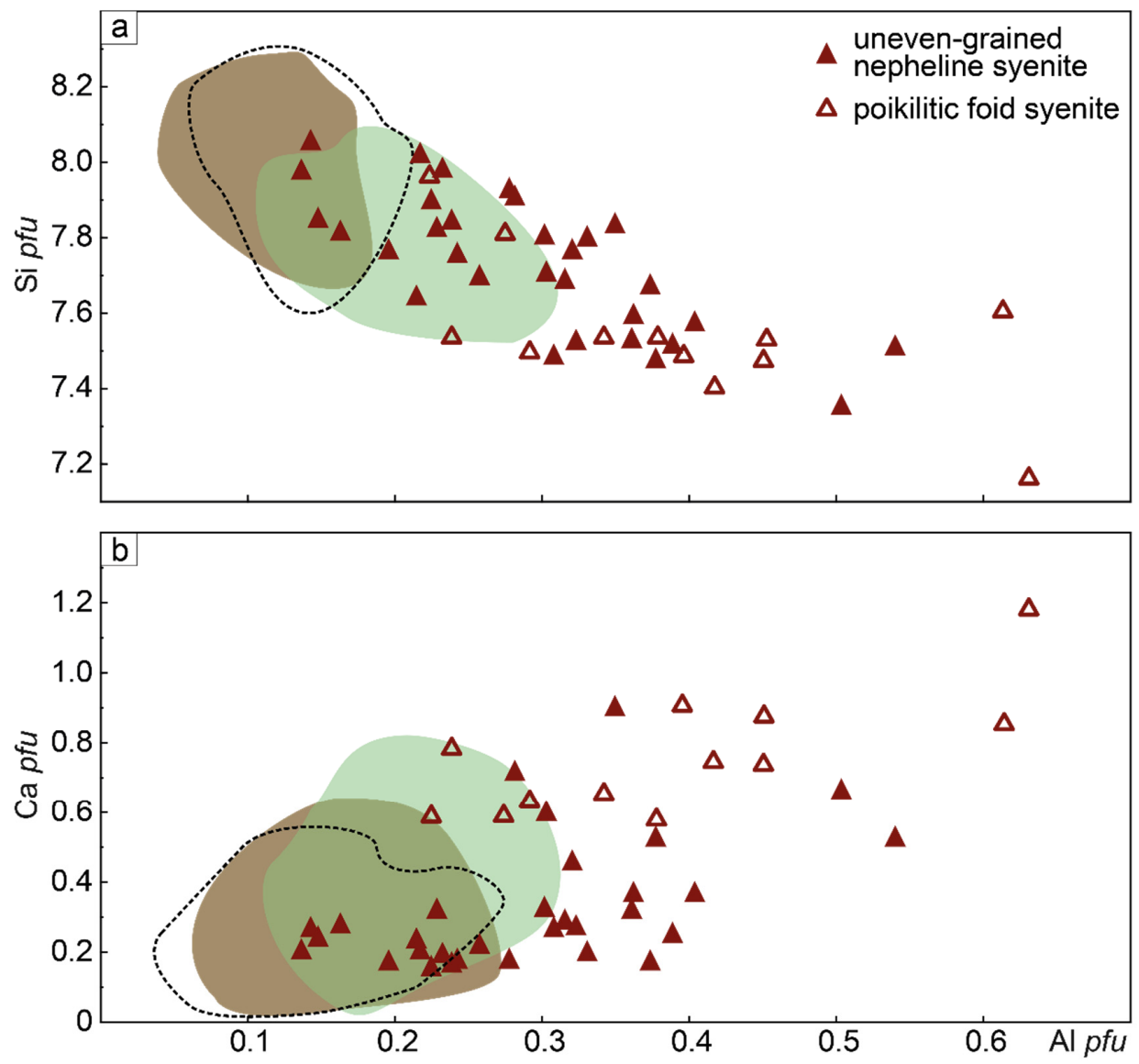

Composition of amphiboles from rocks of Eudialyte complex:

Eudialyte lujavrite

Foyaite

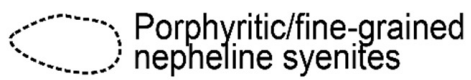

Figure 11. (a) Binary diagram showing the Si concentration in amphiboles from poikilitic rocks as function of $\mathrm{Al}$ content; (b) binary diagram showing the Ca concentration in amphiboles from poikilitic rocks as function of $\mathrm{Al}$ content. The compositions of amphiboles from the rocks of the Eudialyte complex (adapted from [54]) are denoted by colored backgrounds and a dashed line. 


\subsubsection{Clinopyroxenes}

The compositions of clinopyroxenes in the $\mathrm{Mg}-\left(\mathrm{Fe}^{2+}+\mathrm{Mn}\right)-\mathrm{Na}$ system are shown in Figure 12. Representative microprobe analyses of clinopyroxenes are available in Supplementary Table S7. The relict clinopyroxene grains are enriched in magnesium and calcium and correspond in composition to diopside or augite. In addition, there are relict grains of aegirine-augite (64-78 $\mathrm{mol} \%$ Quad, $17-31 \mathrm{~mol} \%$ aegirine, $1.5-6 \mathrm{~mol} \%$ jadeite). The compositions of clinopyroxenes forming rims around resorbed relics of $\mathrm{Ca}-\mathrm{Mg}$-rich clinopyroxenes and also around amphiboles correspond to aegirine-augite and aegirine (17-69 mol\% Quad, 29-78 mol\% aegirine, 2-5 mol\% jadeite). Typical impurities in clinopyroxenes are titanium (median 0.04 apfu in relicts; median 0.06 apfu in rims) and zirconium (median 0.01 apfu in relicts as and as in rims). No differences in the chemical composition of clinopyroxenes from uneven-grained nepheline syenite and poikilitic foid syenite were found.

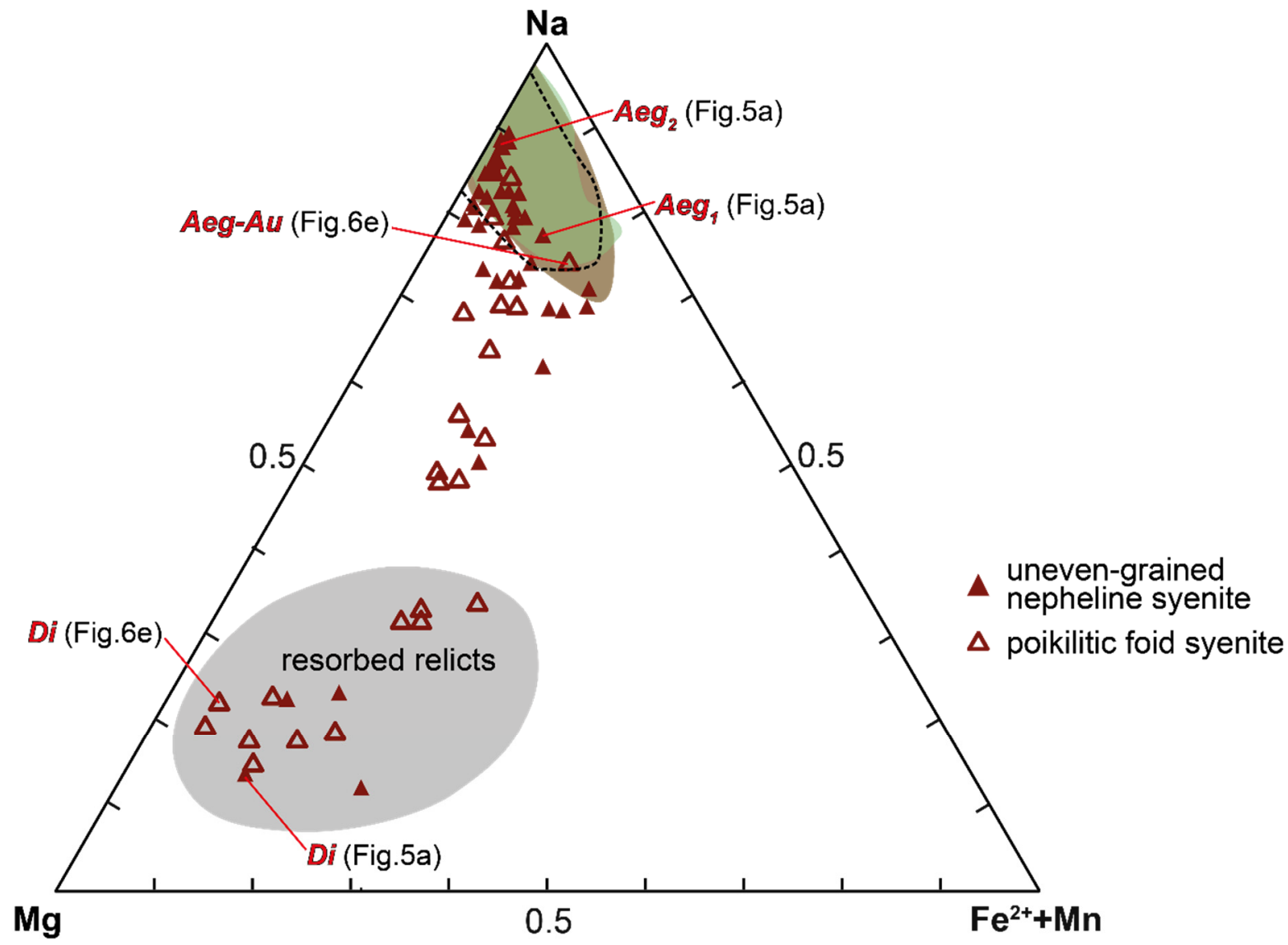

Composition of clinopyroxenes from rocks of Eudialyte complex:

\section{Eudialyte lujavrite}
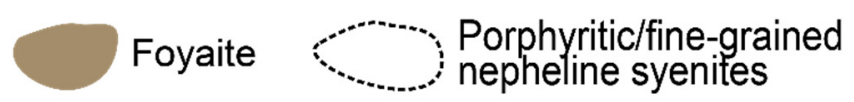

Figure 12. $\mathrm{Mg}-\left(\mathrm{Fe}^{2+}+\mathrm{Mn}\right)-\mathrm{Na}$ systematic of clinopyroxenes from poikilitic rocks. The compositions of clinopyroxenes from the rocks of the Eudialyte complex (adapted from [54]) and composition of resorbed relicts of Ca-Mg-rich clinopyroxenes are denoted by colored backgrounds and a dashed line.

\subsubsection{Other Minerals}

Typical accessory minerals of poikilitic rocks are phlogopite, fluorapatite, titanite, ilmenite, and magnetite. Representative chemical analyses of phlogopite are presented in Supplementary Table S8. Phlogopite is enriched in titanium, and the titanium concentration 
in phlogopite from uneven-grained nepheline syenite is higher (up to $0.24 \mathrm{apfu}$ ) than in phlogopite from poikilitic foid syenite (up to $0.19 \mathrm{apfu}$ ).

Representative chemical analyses of fluorapatite are shown in Supplementary Table S9. Fluorapatite is enriched in strontium (up to $1.31 \mathrm{apfu}$ ) and REE (up to $0.10 \mathrm{Ce} p f u, 0.05 \mathrm{La}$ $p f u$ ), and the Si content does not exceed $0.09 \mathrm{apfu}$. The main substitution scheme in fluorapatite is $2(\mathrm{Ca}, \mathrm{Sr})^{2+} \leftrightarrows \mathrm{Na}^{+}+\mathrm{REE}^{3+}$. In fluorapatite from uneven-grained nepheline syenite, this reaction is shifted to the right, while fluorapatite from poikilitic foid syenite, on the contrary, contains more calcium and strontium (Figure 13a).

Ilmenite usually forms homogeneous grains, but in uneven-grained nepheline syenite, it sometimes contains magnetite lamellae, while in poikilitic foid syenite, on the contrary, ilmenite lamellae are found in magnetite. Homogeneous ilmenite grains are enriched in manganese (up to $0.41 \mathrm{Mn} p f u$ in ilmenite from uneven-grained nepheline syenite, Figure 13b). Representative chemical analyses for ilmenite are presented in Supplementary Table S10.
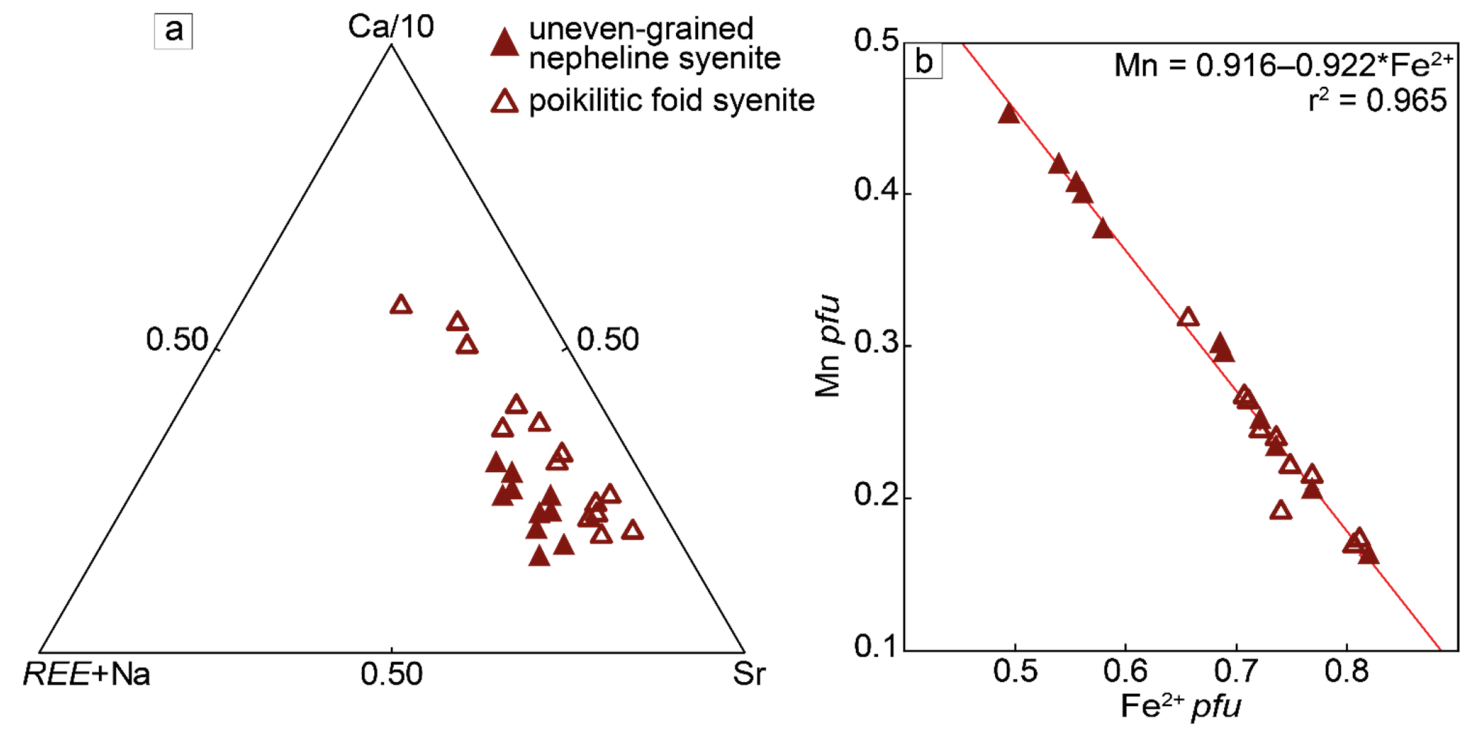

Figure 13. (a) Ca-(REE+Na)-Sr systematic of fluorapatite from poikilitic rocks. Fluorapatite from uneven-grained nepheline syenite is enriched in REE and Na. (b) Binary diagram showing the Fe concentration in ilmenite from poikilitic rocks as a function of Mn content.

Magnetite forms homogeneous grains, lamellae in ilmenite (in uneven-grained nepheline syenite), and grains with ilmenite lamellae (in poikilitic foid syenite). In homogeneous grains, the titanium content is maximal and reaches 0.24 apfu (e.g., a homogeneous magnetite grain in Figure 5d). Representative chemical analyses of magnetite, both homogeneous and with ilmenite lamellae, are shown in Supplementary Table S11.

Representative chemical analyses for titanite are shown in Supplementary Table S12. Titanite contains a large number of elements, such as $\mathrm{Nb}, \mathrm{Fe}, \mathrm{Na}$, and REE, and several exchange mechanisms allowing different cations to enter the structure have been proposed. The most important chemical substitutions responsible for the chemical variations in titanite are illustrated in Figure 14a,b:

$$
2 \mathrm{Ca}^{2+} \leftrightarrows \mathrm{Na}^{+}+\mathrm{REE}^{3+} ; 2 \mathrm{Ti}^{4+} \leftrightarrows \mathrm{Nb}^{5+}+\left(\mathrm{Al}, \mathrm{Fe}^{3+}\right) ; \mathrm{Ti}^{4+} \leftrightarrows \mathrm{Zr}^{4+}
$$

Titanite from poikilitic foid syenite is enriched in calcium and elements that replace titanium $\left(\mathrm{Nb}, \mathrm{Zr}, \mathrm{Al}, \mathrm{Fe}^{3+}\right)$. In titanite from uneven-grained nepheline syenite, on the contrary, the titanium content is maximum, and the calcium content is minimum. 

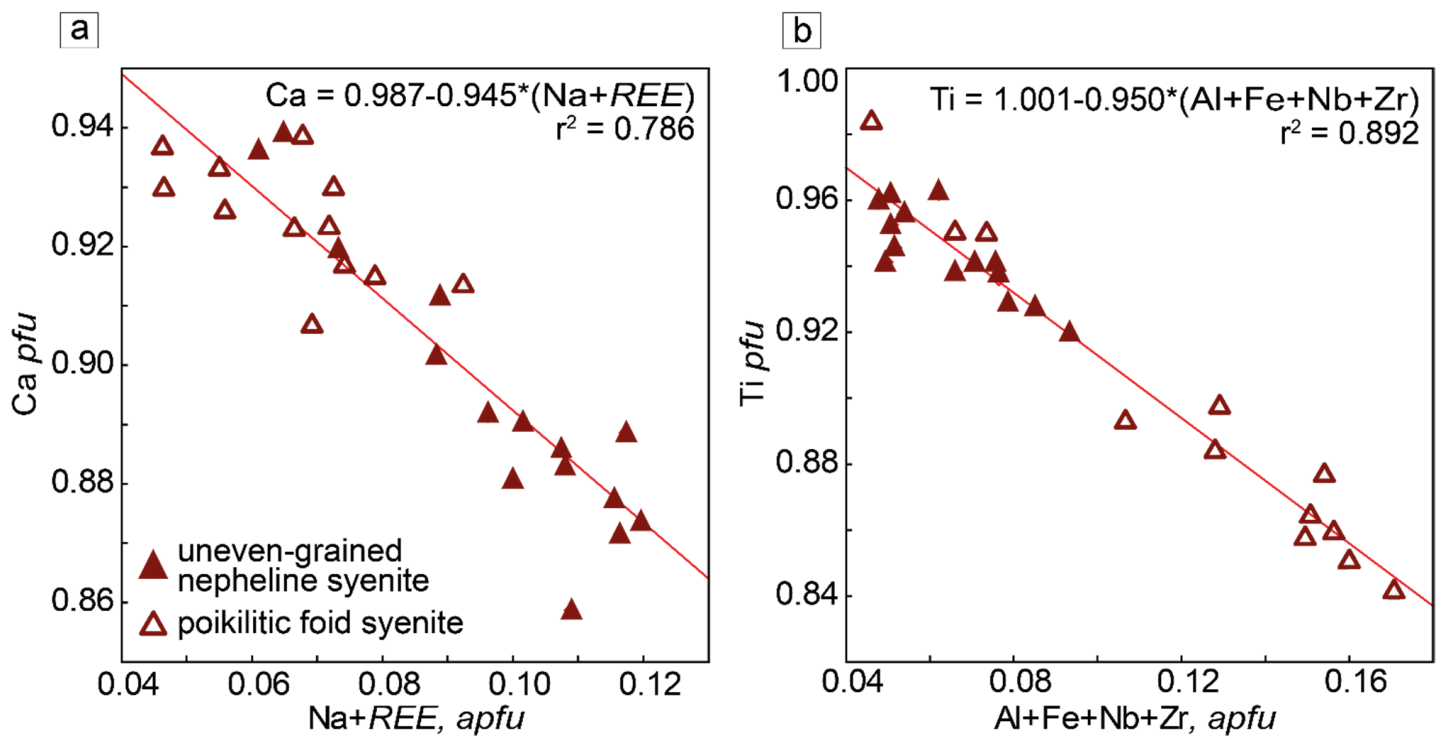

Figure 14. Important substitutions in titanite from poikilitic rocks: (a) substitution in the Ca-site according to the scheme $2 \mathrm{Ca}^{2+} \leftrightarrows \mathrm{Na}^{+}+\mathrm{REE}^{3+} ;(\mathbf{b})$ binary diagram shows that $\mathrm{Ti}$ is involved in a number of substitutions according to the schemes $2 \mathrm{Ti}^{4+} \leftrightarrows \mathrm{Nb}^{5+}+\left(\mathrm{Al}, \mathrm{Fe}^{3+}\right)$ and $\mathrm{Ti}^{4+} \leftrightarrows \mathrm{Zr}^{4+}$

\section{Discussion}

The rocks of the poikilitic complex we studied are formally divided into two groups: uneven-grained nepheline syenite and poikilitic foid syenite. These two groups of rocks are connected by gradual transitions, have a metasomatic texture and a similar mineral (but not modal) composition.

Uneven-grained nepheline syenite formed at the first stage of metasomatic alteration. This rock contains numerous relics of microcline laths, which are intensively replaced by albite and nepheline (Figure 4a). Foyaite is a rock enriched in feldspar (microcline) in both Eudialyte and Layered complexes of the Lovozero massif [29,30,54]). In the cross section along line 1 (Figures $1 \mathrm{~b}$ and $3 \mathrm{a}$ ), it can be seen that in the Eudialyte complex, poikilitic rocks are located either among the foyaite or at the same depth. In uneven-grained nepheline syenites, the content of microcline relics reaches $40 \%$ of the rock volume; the laths of the relict microcline are located chaotically. All this suggests that the protolith was a massive leucocratic feldspar rock, namely, foyaite.

To determine which elements were added to or lost from the rock during the transformation of foyaite into uneven-grained nepheline syenite, we used the method of Grant [68], which involves a pairwise graphical comparison of the compositions of altered and unaltered rocks. Immobile elements should define a line (isocon) passing through the origin, the slope of which represents the ratio of the masses of the altered to the fresh rock. A slope of 1 indicates that there has been no mass change, whereas higher or lower slopes imply a gain or loss of mass (or loss or gain of volume). Figure 15a shows an isocon diagram for a pair of foyaite (unaltered rock) and uneven-grained nepheline syenite (altered rock). To construct this diagram, we used the mean rock compositions from Supplementary Table S2. The line passing closest to the greatest number of elements has a slope of 1 , indicating that this alteration occurred without a change in the mass of the rock (Figure 15a). Conclusions that can be drawn from this isocon diagram are that $\mathrm{Na}_{2} \mathrm{O}, \mathrm{Al}_{2} \mathrm{O}_{3}, \mathrm{CaO}, \mathrm{MgO}, \mathrm{P}_{2} \mathrm{O}_{5}, \mathrm{REE}_{2} \mathrm{O}_{3}$, $\mathrm{TiO}_{2}$, and $\mathrm{F}, \mathrm{S}, \mathrm{CO}_{2}$ were added to the rock during metasomatic alteration, while $\mathrm{K}_{2} \mathrm{O}$, $\mathrm{ZrO}_{2}, \mathrm{Li}_{2} \mathrm{O}, \mathrm{MnO}, \mathrm{Cl}$, and $\mathrm{H}_{2} \mathrm{O}$ were removed.

As mass was conserved during alteration (i.e., no correction needs to be applied to the data), we can investigate the relative importance of metasomatic alteration in controlling the composition of rocks by comparing element abundances directly (Supplementary Table S2, Figure $15 \mathrm{~b}, \mathrm{c}$ ). With the metasomatic replacement of foyaite, an increase in the contents of $\mathrm{Na}_{2} \mathrm{O}$ and $\mathrm{Al}_{2} \mathrm{O}_{3}$ and a decrease in the content of $\mathrm{K}_{2} \mathrm{O}$ occur. This is likely manifested in 
the replacement of microcline by albite and/or nepheline (Figure 4a), in accordance with possible reactions:

$$
\begin{gathered}
\mathrm{KAlSi}_{3} \mathrm{O}_{8} \text { (microcline) }+\mathrm{Na}^{+} \rightarrow \mathrm{NaAlSi}_{3} \mathrm{O}_{8} \text { (albite) }+\mathrm{K}^{+} ; \\
4 \mathrm{KAlSi}_{3} \mathrm{O}_{8} \text { (microcline) }+9 \mathrm{Na}^{+}+8 \mathrm{Al}^{3+}+8 \mathrm{O}_{2} \rightarrow 3 \mathrm{Na}_{3} \mathrm{KAl}_{4} \mathrm{Si}_{4} \mathrm{O}_{16} \text { (nepheline) }+\mathrm{K}^{+} ; \\
5 \mathrm{KAlSi}_{3} \mathrm{O}_{8} \text { (microcline) }+10 \mathrm{Na}^{+}+8 \mathrm{Al}^{3+}+8 \mathrm{O}_{2} \rightarrow \\
3 \mathrm{Na}_{3} \mathrm{KAl}_{4} \mathrm{Si}_{4} \mathrm{O}_{16} \text { (nepheline) }+\mathrm{NaAlSi}_{3} \mathrm{O}_{8} \text { (albite) }+2 \mathrm{~K}^{+} .
\end{gathered}
$$

Because, in addition to the loss of potassium, a decrease in the $\mathrm{SiO}_{2}$ content is also observed, the replacement of the microcline with nepheline can also occur in accordance with the reaction:

$$
\begin{gathered}
2 \mathrm{KAlSi}_{3} \mathrm{O}_{8} \text { (microcline) }+3 \mathrm{Na}^{+}+2 \mathrm{Al}^{3+}+2 \mathrm{O}_{2} \rightarrow \\
\mathrm{Na}_{3} \mathrm{KAl}_{4} \mathrm{Si}_{4} \mathrm{O}_{16} \text { (nepheline) }+2 \mathrm{SiO}_{2}+\mathrm{K}^{+} .
\end{gathered}
$$

When microcline is replaced with nepheline and/or albite, a significant amount of potassium is released. Some of the potassium is removed from the rock, and some, supposedly, is included in the composition of potassium-enriched minerals (phlogopite, amphiboles, orthoclase), which crystallize in the metasomatic process simultaneously with nepheline. We propose a metasomatic origin for these minerals because (1) phlogopite occurs only in poikilitic rocks [28]; (2) magnesio-arfvedsonite from poikilitic rocks contains more magnesium, calcium, aluminum, and fluorine than magnesio-arfvedsonite from foyaite [54]. Potassium is also part of orthoclase, which forms only small laths at the initial stage of metasomatic replacement of foyaite (Figure $5 f$ ) and then appears as large poikilitic crystals.

Furthermore, with metasomatic replacement of foyaite, a significant addition of $\mathrm{TiO}_{2}$ is observed. Titanium is a part of ilmenite, ulvöspinel-rich magnetite, and titanite. The addition of magnesium and titanium is the reason for the crystallization of Ti-enriched phlogopite with thin plates of ilmenite or titanite located along the cleavage. Moreover, as a result of the addition of magnesium, calcium, and titanium, Quad pyroxenes (diopside and augite) and Ca-enriched amphiboles (ferri-katophorite, richterite) crystallized. The sequence of crystallization of pyroxenes and amphiboles from $\mathrm{Ca}$ end-members to $\mathrm{Ca}-\mathrm{Na}$ end-members and Na end-members potentially occurred due to the fact that at the initial stage of metasomatism, almost all of the added sodium was used on crystallization of nepheline, and the calcium addition was very significant (Figure 15b,c). Sodium-rich clinopyroxenes and amphiboles formed later, with the appearance of excess sodium. As a result of the addition of $\mathrm{P}, \mathrm{Ca}, \mathrm{Sr}, \mathrm{F}$, and REE, SrREE-rich fluorapatite crystallized, as did loparite-(Ce), pyrochlore group minerals, and rinkite-(Ce).

Supposedly, the loss of lithium (its content decreases by $48 \%$ ), manganese (by $42 \%$ ), as well as water (in general, the content decreases by $46 \%$ ) and a part of silicon, is associated with the resorption of amphiboles from foyaite. The relict NaSi-enriched amphiboles of the foyaite were probably unstable during metasomatism and were completely resorbed. Indeed, at the initial stages of nephelinization, the activity of silica and the sodium content decrease. This is evidenced by both the sequence of crystallization of pyroxenes and amphiboles $(\mathrm{Ca} \rightarrow \mathrm{Ca}-\mathrm{Na} \rightarrow \mathrm{Na}$ end-members) and the pattern in the arrangement of titanium minerals (ilmenite is surrounded by a titanite rim).

The decrease in the zirconium content could be associated with the resorption of alkaline zirconosilicates, mainly minerals from the eudialyte and lovozerite groups, which are characterizing to unaltered foyaite $[27,28,51,54]$. Part of the zirconium is released, and part is localized first in the form of baddeleyite or zircon and then in the composition of parakeldyshite and minerals of the eudialyte group enriched in calcium and strontium [54]. The sequence of crystallization of zirconium minerals also indicates a low activity of silica and the absence of excess sodium at the initial stage of nephelinization. 

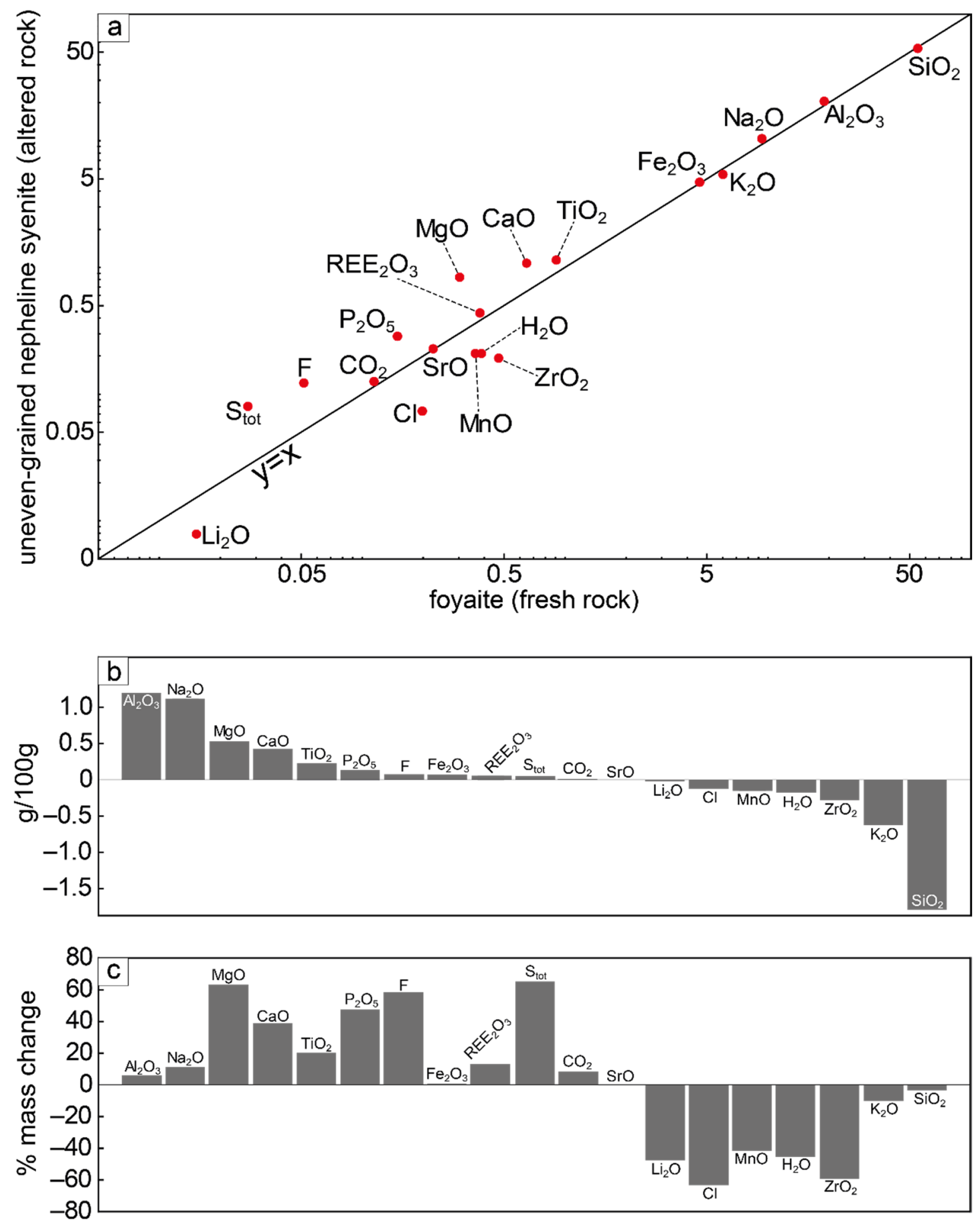

Figure 15. (a) Isocon diagram comparing the chemistry of uneven-grained nepheline syenite (altered rock) and foyaite (fresh rock); (b,c) bar diagrams showing the gains and losses of major oxides and elements.

With the metasomatic replacement of foyaite, the sulfur content increases most significantly (by 65\%). Sulfur is localized in the composition of sulfides, as well as in vishnevite, which replaces nepheline (Figure $4 \mathrm{a}$ ) and feldspar in accordance with the reactions:

$3 \mathrm{Na}_{3} \mathrm{KAl}_{4} \mathrm{Si}_{4} \mathrm{O}_{16}$ (nepheline) $+2 \mathrm{SO}_{4}{ }^{2-}+2 \mathrm{H}_{2} \mathrm{O}+7 \mathrm{Na}^{+} \rightarrow$

$2 \mathrm{Na}_{8} \mathrm{Al}_{6} \mathrm{Si}_{6} \mathrm{O}_{24}\left(\mathrm{SO}_{4}\right) \cdot 2 \mathrm{H}_{2} \mathrm{O}$ (vishnevite) $+3 \mathrm{~K}^{+}$;

$2 \mathrm{KAlSi}_{3} \mathrm{O}_{8}$ (microcline) $+8 \mathrm{Na}^{+}+4 \mathrm{Al}^{3+}+4 \mathrm{O}_{2}+\mathrm{SO}_{4}{ }^{2-}+2 \mathrm{H}_{2} \mathrm{O} \rightarrow$

$\mathrm{Na}_{8} \mathrm{Al}_{6} \mathrm{Si}_{6} \mathrm{O}_{24}\left(\mathrm{SO}_{4}\right) \cdot 2 \mathrm{H}_{2} \mathrm{O}$ (vishnevite) $+2 \mathrm{~K}^{+}$. 
Often, microcline and nepheline are replaced by an aggregate of vishnevite and natrolite (Figure 6c) according to reactions such as:

$$
\begin{gathered}
3 \mathrm{KAlSi}_{3} \mathrm{O}_{8} \text { (microcline) }+10 \mathrm{Na}^{+}+5 \mathrm{Al}^{3+}+\mathrm{O}_{2}+\mathrm{SO}_{4}{ }^{2-}+4 \mathrm{H}_{2} \mathrm{O} \rightarrow \\
\mathrm{Na}_{8} \mathrm{Al}_{6} \mathrm{Si}_{6} \mathrm{O}_{24}\left(\mathrm{SO}_{4}\right) \cdot 2 \mathrm{H}_{2} \mathrm{O} \text { (vishnevite) }+\mathrm{Na}_{2}\left(\mathrm{Si}_{3} \mathrm{Al}_{2}\right) \mathrm{O}_{10} \cdot 2 \mathrm{H}_{2} \mathrm{O} \text { (natrolite) }+3 \mathrm{~K}^{+} .
\end{gathered}
$$

Progress in these reactions led to the formation of complete pseudomorphs of vishnevite over nepheline. At the same time, potassium—released in the reactions microcline $\rightarrow$ nepheline, microcline $\rightarrow$ vishnevite, and nepheline $\rightarrow$ vishnevite-was part of orthoclase. As a boundary between the first (formation of uneven-grained nepheline syenite) and the second (formation of poikilitic foid syenite) stages of metasomatism, we conventionally consider the appearance of orthoclase with single poikilitic inclusions of vishnevite and nepheline.

In order to assess which elements were added or removed from the rock at the second stage of metasomatism, we also used the method of Grant [67]. We compared the mean compositions of the uneven-grained nepheline syenite (protolith) and poikilitic foid syenite (Figure 16). The line passing closest to the greatest number of elements has a slope of 1 , indicating that this alteration occurred without any change in the mass of the rock (Figure 16a). It can be seen that the results are the same as when comparing the unevengrained nepheline syenite-foyaite pair. Sodium oxide, $\mathrm{Al}_{2} \mathrm{O}_{3}, \mathrm{CaO}, \mathrm{MgO}, \mathrm{P}_{2} \mathrm{O}_{5}, \mathrm{REE}_{2} \mathrm{O}_{3}$, and $\mathrm{F}, \mathrm{S}, \mathrm{CO}_{2}$ were added to the rock during metasomatic alteration, $\mathrm{K}_{2} \mathrm{O}, \mathrm{ZrO}_{2}, \mathrm{Li}_{2} \mathrm{O}$, $\mathrm{MnO}, \mathrm{SiO}_{2}$, and $\mathrm{Fe}_{2} \mathrm{O}_{3}$ were removed.

There is an important difference in the behavior of chlorine, water, titanium, and iron. At the first stage of metasomatic alteration, chlorine and water are lost from the rock, and at the second, on the contrary, they are added. As mentioned above, the probable cause of the loss of chlorine and water at the first stage of metasomatism is the complete resorption of amphiboles and EGM. The ionic radius of fluorine (1.33 $\AA$ ) is very close to the ionic radii of oxygen and hydroxyl (1.40 and $1.37 \AA$, respectively; [69]). Fluorine can readily substitute for $\mathrm{O}$ on the vertices of aluminate or silicate tetrahedra, which promotes its solubility in the silicate melt [70,71], whereas incorporation of $\mathrm{Cl}(1.82 \AA)$ is restricted to interstitial or network-modifier sites, and this limits their solubility in the melt. Therefore, fluorine is predominantly distributed in the silicate melt and chlorine in the fluid [72]. In alkaline systems, the transition between silicate melts and hydrothermal solution is gradual. Considering this fact and the behavior of halogens, we can draw the following conclusion. At the first stage of metasomatism, the foyaite was exposed to a fluid-saturated melt (or melt-solution?) and at the second, to a hydrothermal aqueous solution.

Intensive replacement of ilmenite and Ti-rich magnetite with titanite, phlogopite, and aegirine is the reason for the loss of titanium and iron at the second stage of metasomatism.

Thus, poikilitic rocks were formed during metasomatic alteration of foyaite as a result of the gain of $\mathrm{Na}_{2} \mathrm{O}, \mathrm{Al}_{2} \mathrm{O}_{3}, \mathrm{CaO}, \mathrm{MgO}, \mathrm{SrO}, \mathrm{P}_{2} \mathrm{O}_{5}, \mathrm{REE}_{2} \mathrm{O}_{3}$, and volatiles. In the Lovozero massif, this set of elements is characteristic for urtite, i.e., an almost monomineral nepheline rock enriched in SrREE-fluorapatite and other phosphates, as well as loparite-(Ce) [30]. Therefore, the process of formation of poikilitic rocks can be called urtitization of foyaite.

As shown by field investigations and as can be seen in the cross section (Figure $3 a$ ), there is no urtite (or other monomineral feldspatoid rocks) near the contact with the poikilitic rocks. Poikilitic rocks are located either among foyaite or among eudialyte lujavrite. We have not established any signs of metasomatic influence from the lujavrite; on the contrary, the surrounded lujavrite exhibits signs of metasomatic alterations at the contact with poikilitic rocks (Figure 7).

In our previous works, we established that the differentiation of the peralkaline melt during the formation of the rocks of the Lovozero massif proceeded in the following path: lujavrite $\rightarrow$ foyaite $\rightarrow$ urtite. In this sequence, the concentrations of sodium, high field strength elements (HFSE), and volatiles increase (Figure 9). With the formation of the rhythm of the Layered complex, a portion of the peralkaline melt evolved from top to 
bottom. Furthermore, the residual melt could be separated and subsequently crystallized in the form of sheet-like bodies and lenses, as it is observed in the middle part of the Layered complex. Similarly, foyaite lenses in the Eudialyte complex were formed by the segregation of a residual, highly evolved melt [54].
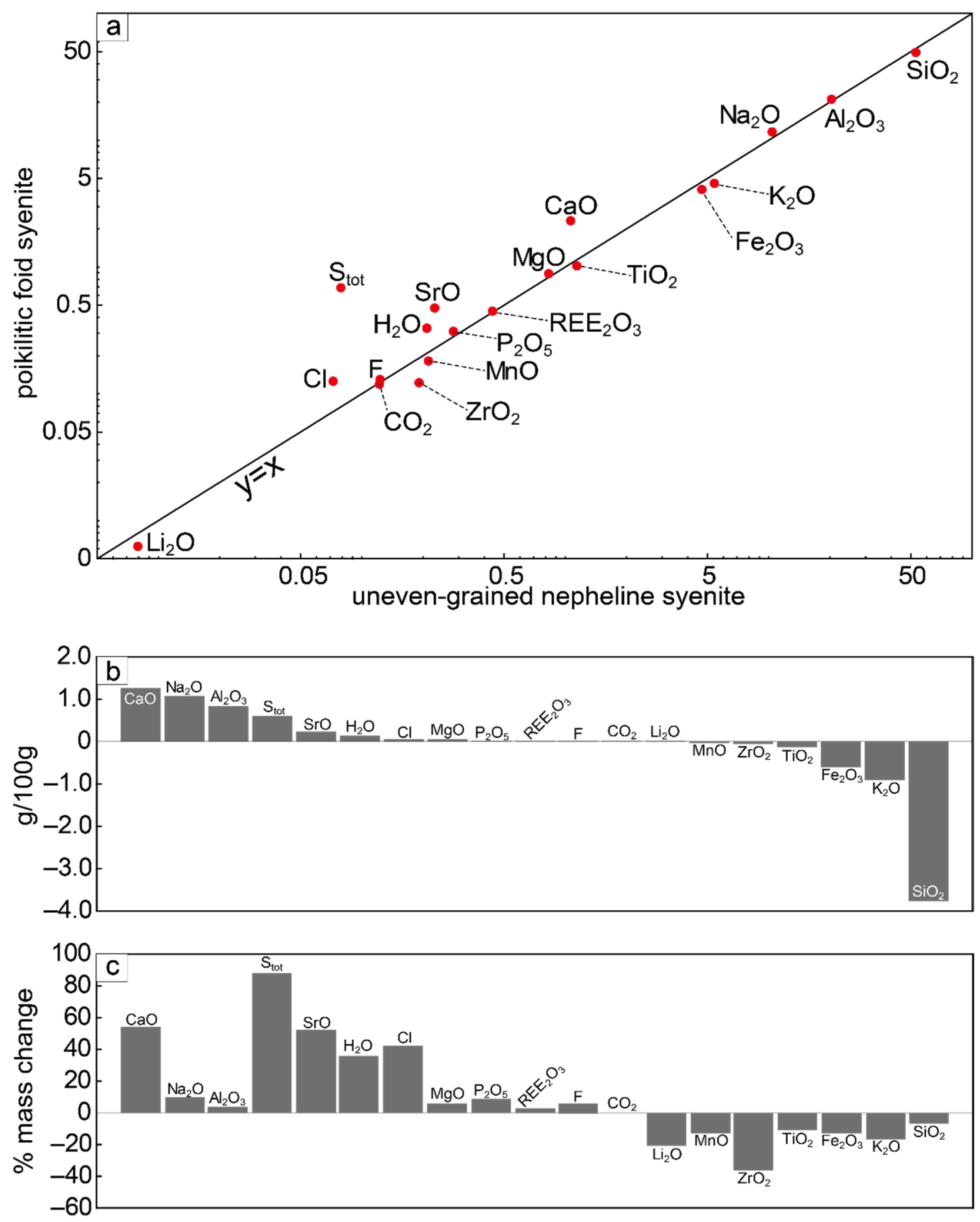

Figure 16. (a) Isocon diagram comparing the chemistry of poikilitic foid syenite (altered rock) and uneven-grained nepheline syenite (fresh rock); $(\mathbf{b}, \mathbf{c})$ bar diagrams showing the gains and losses of major oxides and elements.

In evolution of peralkaline magmas, the transition from magmatic melt (minerals crystallize from a silicate melt) to hydrothermal solution (minerals crystallize from an aqueous solution) occurs without critical events. Late magmatic hydrothermal solution did not separate during crystallization (for example, by migration of the solution externally 
to the crystallizing rock) but remained in the rock and caused extensive autometasomatic changes in previously crystallized minerals. This solution, as shown by experimental studies [73], can be " . . strongly enriched in dissolved solids $\left(\mathrm{SiO}_{2}+\mathrm{Al}_{2} \mathrm{O}_{3}+\mathrm{Na}_{2} \mathrm{O}\right.$, in range 40-50 wt\%)". In the sequence lujavrite $\rightarrow$ foyaite $\rightarrow$ urtite, the hydrothermal stage could have occurred after the crystallization of urtite. Indeed, in urtite of the Layered complex, almost all nepheline (and feldspar) is replaced by natrolite with very small pyrite inclusions. However, if the initial melt was significantly enriched in volatiles, the hydrothermal stage could begin after the formation of foyaite. It is known that the Eudialyte complex was formed later than the Layered one [29,30] from peralkaline melts, initially rich in volatiles and HFSE.

We propose the following two paths of differentiation of the peralkaline melt depending on the initial content of volatile components:

(1) Low concentration of volatiles: lujavrite $\rightarrow$ foyaite $\rightarrow$ urtite $\rightarrow$ natrolitization

$\mathrm{m}$ a g m a t i c s t a g e hydrothermal stage;
(2) High concentration of volatiles: lujavrite $\rightarrow$ foyaite $\rightarrow$ urtitization $\rightarrow$ natrolitization magmatic stage $\quad \mathbf{h} \mathbf{y} \mathbf{d} \mathbf{r} \mathbf{t} \mathbf{h}$ er $\mathbf{m}$ a $\mathbf{l} \mathbf{s} \mathbf{t}$ a $\mathbf{g}$ e.

Based on the previous arguments, we can conclude that poikilitic rocks arose as a result of autometasomatic alteration of foyaite and call this process autometasomatic urtitization.

According to Khomyakov [15], pegmatites in the Layered complex are associated precisely with urtite. This author notes that pegmatites with rare metal mineralization are confined to HFSE- and REE-enriched urtite. Pegmatites form lenses at the contacts of rhythms, while the underlying lujavrite is almost completely unchanged, and the overlying urtite contain numerous apophyses of pegmatite. Khomyakov [15] points out that pegmatites " ... commonly replace the horizons of such rocks with the formation of pegmatoid beds $0.2-2.5 \mathrm{~m}$ thick, which have been traced, with breaks, throughout the entire massif".

Pegmatites in the Layered complex are the end of the evolutionary path lujavrite $\rightarrow$ foyaite $\rightarrow$ urtite $\rightarrow$ (pegmatite) (Figure 17a). Yubileinaya pegmatite is shown in Figure 17b as an example of pegmatite formed with such a sequence. Similarly, the formation of pegmatites associated with poikilitic rocks occurs according to the scheme lujavrite $\rightarrow$ foyaite $\rightarrow$ urtitized foyaite $\rightarrow$ (pegmatite) (Figure 17c). Sirenevaya pegmatite is shown in Figure $17 \mathrm{~d}$ as an example of pegmatite formed in such a sequence.

The process of urtitization is essential in the concentration of rare elements, because during the crystallization of urtite (but not during urtitization) a large amount of these elements form accessory minerals in the rock itself, such as loparite-(Ce), lueshite, minerals of the eudialyte and lovozerite groups, fluorapatite and stronadelphite, lomonosovite, and murmanite. In the process of urtitization, mainly nepheline is precipitated, and the residual solution is significantly enriched in rare and trace elements ( $\mathrm{REE}, \mathrm{Zr}, \mathrm{Ti}, \mathrm{P}, \mathrm{Be}$ ). In addition, the dissolution of foyaite minerals presumably leads to additional enrichment of the residual hydrothermal solution with potassium, lithium, and manganese. Thus, $\mathrm{K}_{2} \mathrm{O}$, $\mathrm{ZrO}_{2}, \mathrm{Li}_{2} \mathrm{O}, \mathrm{MnO}, \mathrm{SiO}_{2}$, and $\mathrm{Fe}_{2} \mathrm{O}_{3}$, which are released during the metasomatic alteration of foyaite, are part of the minerals of pegmatites spatially associated with poikilitic rocks.

Table 2 provides a list of minerals most typical of pegmatites associated with poikilitic rocks. Indeed, these pegmatites contain a wide variety of titanosilicates of lithium, potassium, and manganese (e.g., lintisite, kupletskite, neptunite), silicates of lithium and potassium (e.g., tainiolite, polylithionite), phosphates and silicophosphates (e.g., belovite-(Ce) and steenstrupine-(Ce)), REE-rich minerals (e.g., sazhinite-(Ce)) and beryllium (beryllite, bertrandite). 

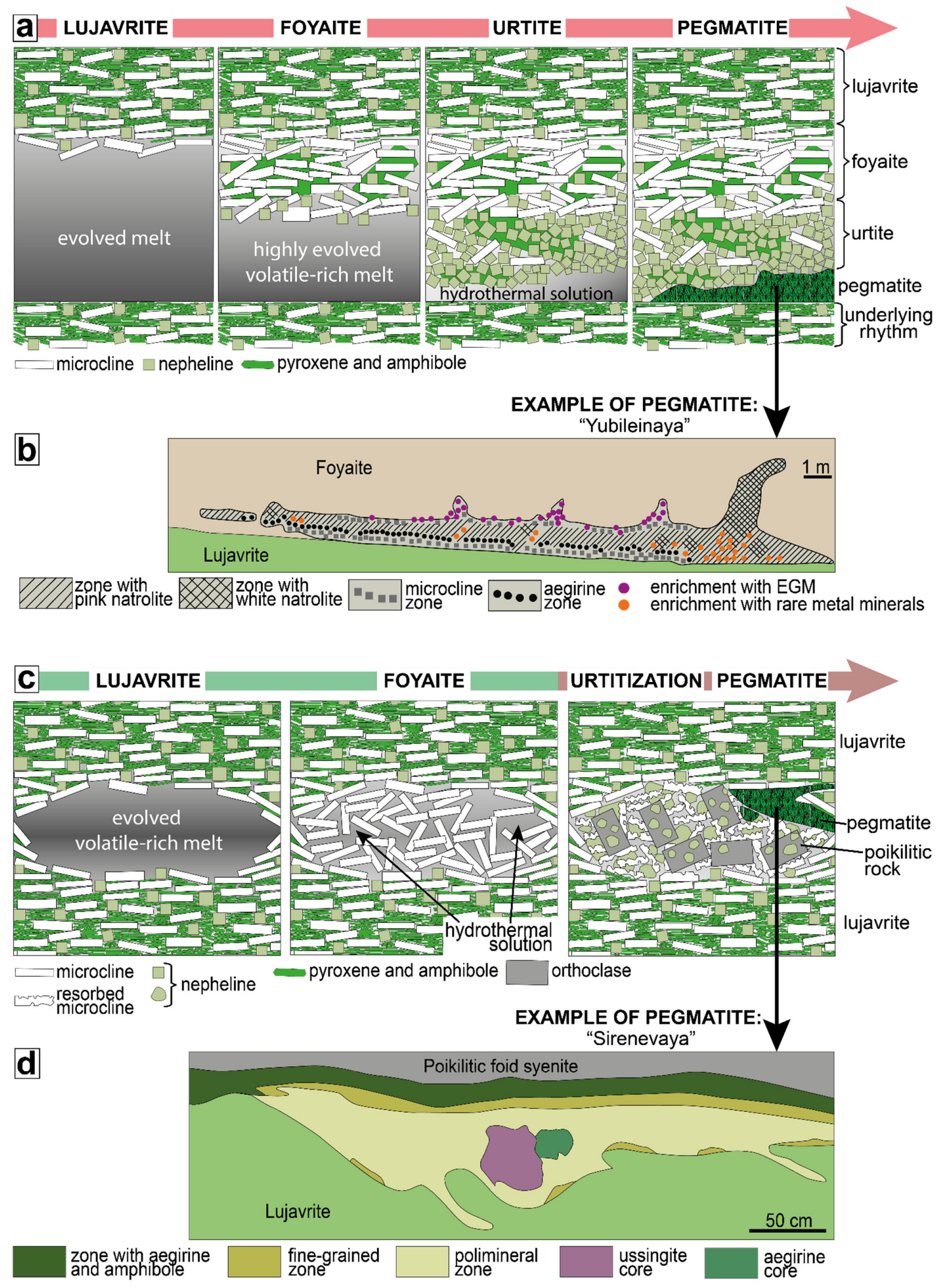

Figure 17. (a) Schematic representation of the evolutionary path lujavrite $\rightarrow$ foyaite $\rightarrow$ urtite $\rightarrow$ (pegmatite), which takes place during the formation of the rhythms of the Layered complex; the color of the arrow corresponds to that in Figure 9; (b) example of pegmatite formed in a sequence lujavrite $\rightarrow$ foyaite $\rightarrow$ urtite $\rightarrow$ (pegmatite); scheme of Yubileinaya pegmatite adapted from [25]; (c) schematic representation of the evolutionary path lujavrite $\rightarrow$ foyaite $\rightarrow$ urtitized foyaite $\rightarrow$ (pegmatite), which takes place during the formation of the poikilitic rocks in the Eudialyte complex; the color of the arrow corresponds to that in Figure 9; (d) example of pegmatite formed in a sequence lujavrite $\rightarrow$ foyaite $\rightarrow$ urtitized foyaite $\rightarrow$ (pegmatite); scheme of Sirenevaya pegmatite adapted from [25]. 
It is difficult to assess the PT conditions for the formation of poikilitic rocks because the rocks are not in equilibrium. It is reasonable to assume that the upper temperature limit is the temperature of protolith (foyaite) crystallization. According to [54], the foyaite of the Eudialyte complex crystallized at a temperature of about $550^{\circ} \mathrm{C}$. Metasomatic reactions took place during further cooling after the foyaite crystallization; hence, the poikilitic rocks crystallized at temperatures below $550{ }^{\circ} \mathrm{C}$. The Lovozero massif is considered, based on geological data, to be a subvolcanic complex [29], and the maximum total pressure should not exceed $1.5 \mathrm{kbar}$ [14]. The abundance of sulfate-bearing feldspathoids and absence of primary pyrrhotite at poikilitic rock indicate oxidizing conditions above the NNO (nickel-nickel oxide) buffer [74].

Poikilitic rocks are important for studying the composition and evolution of fluids associated with peralkaline rocks. It is known that alkaline massifs, including Lovozero, are abnormally saturated with molecular hydrogen together with other hydrocarbons (HCs) of putative abiotic origin [75], but the reasons for the appearance of these gases are debatable [76]. During the formation of poikilitic rocks, numerous mineral reactions occur with the participation of elements of variable valence (e.g., the replacement of magnesio-arfvedsonite with aegirine). Such reactions have been found to be responsible for the generation of molecular hydrogen [77]. Therefore, further detailed studies of the mineralogy of poikilitic rocks are very important.

As stated in the Introduction, poikilitic rocks are widespread in other peralkaline massifs of the world. Khibiny massif consists dominantly of foyaite (about $70 \%$ of the outcrop area) and foidolite ( $8 \%$ of the outcrop area) that intruded into the foyaite massif along the Main Ring fault $[32,78,79]$. Poikilitic nepheline syenite, rischorrite (consist of poikilitic alkali feldspar with nepheline inclusions), commonly occurs between the rocks of the Main Ring and the foyaite. The researchers believe that rischorrite was formed under the metasomatic influence of foidolite intrusion on the surrounded foyaite $[79,80]$. Thus, the way of formation of rischorrite in the Khibiny massif is very similar to the manner of formation of the poikilitic rocks in the Lovozero massif. The difference is that in the Lovozero massif, poikilitic rocks were formed as a result of autometasomatic alteration of foyaite, and in the Khibiny massif, such rocks were of contact metasomatic origin.

The naujaite (rock consisting of poikilitic alkali feldspar with sodalite inclusions) of the Ilímaussaq massif has been found to be of magmatic origin. This massif formed from three melt batches, successively crystallizing the augite syenite, a peralkaline granite, and various nepheline syenites (roof series) [81]. The roof series crystallized from the top downwards, forming the succession of pulaskite (nepheline-bearing alkali feldspar syenite), foyaite, sodalite foyaite, and naujaite. The contacts of these rocks grade into each other, but blocks of the uppermost rocks were loosened from the temporary roof of the magma chamber and engulfed by the underlying crystallizing rocks [82].

The formation of a poikilitic texture in peralkaline rocks probably occurs both during (auto)metasomatism and during magmatic crystallization. However, such a texture appears at a late stage of magmatic differentiation, when a gradual transition from magmatic melt to hydrothermal solution occurs.

\section{Conclusions}

Poikilitic rocks in the Lovozero massif were formed as a result of autometasomatic alteration (urtitization) of foyaite. There are two stages in this process: nephelinization + albitization and vishnevitization + orthoclasization. At the first stage, uneven-grained nepheline syenite is formed, and at the second stage, poikilitic syenite is crystallized.

During urtitization, $\mathrm{Na}_{2} \mathrm{O}, \mathrm{Al}_{2} \mathrm{O}_{3}, \mathrm{CaO}, \mathrm{MgO}, \mathrm{P}_{2} \mathrm{O}_{5}, \mathrm{REE}_{2} \mathrm{O}_{3}$, and $\mathrm{F}, \mathrm{S}, \mathrm{CO}_{2}$ are added and $\mathrm{K}_{2} \mathrm{O}, \mathrm{ZrO}_{2}, \mathrm{Li}_{2} \mathrm{O}, \mathrm{MnO}, \mathrm{SiO}_{2}$, and $\mathrm{Fe}_{2} \mathrm{O}_{3}$ are removed.

The reason for the spatial association of pegmatites and poikilitic rocks is that pegmatites are the final stage of differentiation of the peralkaline melt in path: lujavrite $\rightarrow$ foyaite $\rightarrow$ urtite (or urtitization of foyaite with formation of poikilitic rocks) $\rightarrow$ pegmatite. 
The reason for the abundance of rare elements in pegmatites associated with poikilitic rocks is that almost only one nepheline is deposited during urtitization, whereas during the magmatic crystallization of urtite, rare and trace elements form accessory minerals in the rock and are less concentrated in the residual solution.

Thus, the formation of poikilitic rocks is the pre-pegmatite stage of the peralkaline process, and its significant role is the additional concentration of trace elements (rare metals) in the solution, from which pegmatite veins are later formed.

Supplementary Materials: The following are available online at https: / www.mdpi.com/article / 10.3390/min11090974/s1, Table S1: Parameters of chemical analyses; Table S2: Wet chemistry analyses of rocks; Table S3: Representative microprobe analyses of feldspar; Table S4: Representative microprobe analyses of nepheline; Table S5: Representative microprobe analyses of vishnevite; Table S6: Representative microprobe analyses of amphiboles; Table S7: Representative microprobe analyses of clinopyroxenes; Table S8: Representative microprobe analyses of phlogopite; Table S9: Representative microprobe analyses of fluorapatite; Table S10: Representative microprobe analyses of ilmenite; Table S11: Representative microprobe analyses of magnetite; Table S12: Representative microprobe analyses of titanite.

Author Contributions: Conceptualization, J.A.M.; methodology, J.A.M., Y.A.P.; validation, J.A.M., Y.A.P., and A.O.K.; investigation, J.A.M., Y.A.P., and O.F.G.; data curation, Y.A.P., A.V.B.; writingoriginal draft preparation, J.A.M.; writing-review and editing, A.O.K.; visualization, Y.A.P., J.A.M.; investigation, V.N.Y. All authors have read and agreed to the published version of the manuscript.

Funding: Field work was funded by Russian Science Foundation, project no. 21-47-09010. Microprobe and wet chemical analyses were funded by the Ministry of Science and Higher Education of the Russian Federation, project no. 0226-2019-0051.

Acknowledgments: We are grateful to reviewers from MDPI who helped us improve the presentation of our results.

Conflicts of Interest: The authors declare no conflict of interest.

\section{References}

1. Jahns, R.H.; Burnham, C.W. Experimental Studies of Pegmatite Genesis; 1, A model for the derivation and crystallization of granitic pegmatites. Econ. Geol. 1969, 64, 843-864. [CrossRef]

2. Černý, P. Rare-element granitic pegmatites. Part I: Anatomy and internal evolution of pegmatite deposits. Geosci. Canada 1991, 18, 49-67.

3. Simmons, W.B.S.; Webber, K.L. Pegmatite genesis: State of the art. Eur. J. Mineral. 2008, 20, 421-438. [CrossRef]

4. London, D. A petrologic assessment of internal zonation in granitic pegmatites. Lithos 2014, 184-187, 74-104. [CrossRef]

5. Kesler, S.E.; Gruber, P.W.; Medina, P.A.; Keoleian, G.A.; Everson, M.P.; Wallington, T.J. Global lithium resources: Relative importance of pegmatite, brine and other deposits. Ore Geol. Rev. 2012, 48, 55-69. [CrossRef]

6. London, D.; Evensen, J.M. Beryllium in Silicic Magmas and the Origin of Beryl-Bearing Pegmatites. Rev. Mineral. Geochem. 2002, 50, 445-486. [CrossRef]

7. London, D. Internal differentiation of rare-element pegmatites: Effects of Boron, Phosphorus and Fluorine. Geochim. Cosmochim. Acta 1987, 51, 403-420. [CrossRef]

8. Fersman, A.E. Pegmatites; Izdatel'stvo Akademii Nauk: Moscow, Russia, 1960.

9. Cameron, E.N. Internal structure of granitic pegmatites. Econ. Geol. 1949, 2, 115. [CrossRef]

10. Zavaritskii, A.N. About the pegmatites as intermediate formations between the eruption rock and the ore veins. ZVMO 1947, 37-50.

11. Marks, M.A.W.; Markl, G. A Global Review on Agpaitic Rocks. Earth-Sci. Rev. 2017, 173, 229-258. [CrossRef]

12. Bailey, J.C.; Gwozdz, R.; Rose-Hansen, J.; Sørensen, H. Geochemical overview of the Ilímaussaq Alkaline complex, South Greenland. Geol. Greenland Surv. Bull. 2001, 190, 35-53. [CrossRef]

13. Sørensen, H. Agpaitic Nepheline Syenites: A Potential Source of Rare Elements. Appl. Geochem. 1992, 7, 417-427. [CrossRef]

14. Kogarko, L.N. Problems of Genesis of Agpaitic Magmas; Nauka: Moscow, Russia, 1977.

15. Khomyakov, A.P. Mineralogy of Hyperagpaitic Alkaline Rocks; Oxford Scientific Publications: Oxford, UK; Clarendon Press: Oxford, UK, 1995.

16. Borst, A.M.; Friis, H.; Nielsen, T.F.D.; Waight, T.E. Bulk and Mush Melt Evolution in Agpaitic Intrusions: Insights from Compositional Zoning in Eudialyte, Ilímaussaq Complex, South Greenland. J. Petrol. 2018, 59, 589-612. [CrossRef]

17. Müller-Lorch, D.; Marks, M.A.W.; Markl, G. Na and K distribution in agpaitic pegmatites. Lithos 2007, 95, 315-330. [CrossRef]

18. Mysen, B.O.; Richet, P. Silicate Glasses and Melts; Elsevier: Amsterdam, The Netherlands, 2018. 
19. Le Losq, C.; Mysen, B.O.; Cody, G.D. Water and Magmas: Insights about the water solution mechanisms in alkali silicate melts from infrared, raman, and 29Si solid-state NMR spectroscopies. Prog. Earth Planet Sci. 2015, 2, 22. [CrossRef]

20. Moulson, A.J.; Roberts, J.P. Water in silica glass. Trans. Faraday Soc. 1961, 57, 1208. [CrossRef]

21. Xue, X.; Kanzaki, M. Dissolution mechanisms of water in depolymerized silicate melts: Constraints from $1 \mathrm{H}$ and $29 \mathrm{Si}$ NMR Spectroscopy and ab initio calculations. Geochim. Cosmochim. Acta 2004, 68, 5027-5057. [CrossRef]

22. Zotov, N.; Keppler, H. The influence of water on the structure of hydrous sodium tetrasilicate glasses. Am. Mineral. 1998, 83, 823-834. [CrossRef]

23. Sørensen, H.; Larsen, M.L. The hyper-agpaitic stage in the evolution of the Ilímaussaq alkaline complex, South Greenland. Geol. Greenland Surv. Bull. 2001, 190, 83-94. [CrossRef]

24. Sørensen, H. The agpaitic rocks-an overview. Mineral. Mag. 1997, 61, 485-498. [CrossRef]

25. Pekov, I.V. Lovozero Massif: History of Investigations, Pegmatites, Minerals; Ocean Pictures Ltd.: Moscow, Russia, 2001.

26. Marks, M.; Markl, G. Ilímaussaq 'En miniature': Closed-system fractionation in an agpaitic dyke rock from the Gardar Province, South Greenland (contribution to the mineralogy of ilímaussaq No. 117). Mineral. Mag. 2003, 67, 893-919. [CrossRef]

27. Vlasov, K.A.; Kuzmenko, M.Z.; Eskova, E.M. The Lovozero Alkaline Massif; Izdatel'stvo Akademii Nauk: Moscow, Russia, 1959.

28. Semenov, E.I. Mineralogy of the Lovozero Alkaline Massif; Nauka: Moscow, Russia, 1972.

29. Bussen, I.V.; Sakharov, A.S. Petrology of the Lovozero Alkaline Massif; Nauka: Leningrad, Russia, 1972.

30. Gerasimovsky, V.I.; Volkov, V.P.; Kogarko, L.N.; Polyakov, A.I.; Saprykina, T.V.; Balashov, Y.A. Geochemistry of the Lovozero Alkaline Massif; Nauka: Moscow, Russia, 1966.

31. Arzamastsev, A.A.; Arzamastseva, L.V.; Zhirova, A.M.; Glaznev, V.N. Model of Formation of the Khibiny-Lovozero ore-bearing volcanic-plutonic complex. Geol. Ore Depos. 2013, 55, 341-356. [CrossRef]

32. Kostyleva-Labuntsova, E.E.; Borutskii, B.E.; Sokolova, M.N.; Shlykova, Z.V. Mineralogy of the Khibiny Massif: Magmatism and Postmagmatic Transformations; Nauka: Moscow, Russia, 1978.

33. Kupletskii, B.M. Kukisvumchorr i Prilegayushchie k Nemu Massivy Tsentralnoi Chasti Khibinskikh Tundr. Trudy Soveta Po Izucheniiu Proizvoditel'nykh Sil, Seriia Kolskaia. Materialy Po Petrografii i Geokhimii Kolskogo Poluostrova 1932, 2, 5-72.

34. Yakovenchuk, V.N.; Ivanyuk, G.Y.; Pakhomovsky, Y.A.; Men'shikov, Y.P. Khibiny; Laplandia minerals: Apatity, Russia, 2005.

35. Larsen, L.M.; Sorensen, H. The Ilímaussaq intrusion-progressive crystallization and formation of layering in an agpaitic magma. Geol. Soc. Spec. Publ. 1987, 30, 473-488. [CrossRef]

36. Sørensen, H.; Larsen, L.M. Layering in the Ilímaussaq alkaline intrusion, South Greenland. Orig. Igneous Layering 1987, $196,1-28$.

37. Schilling, J.; Marks, M.A.W.; Wenzel, T.; Vennemann, T.; Horváth, L.; Tarassoff, P.; Jacob, D.E.; Markl, G. The Magmatic to hydrothermal evolution of the intrusive Mont Saint-Hilaire complex: Insights into the late-stage evolution of peralkaline rocks. J. Petrol. 2011, 52, 2147-2185. [CrossRef]

38. Piilonen, P.C.; McDonald, A.M.; Lalonde, A.E. The crystal chemistry of aegirine from Mont Saint-Hilaire, Quebec. Can. Mineral. 1998, 36, 779-791.

39. Kramm, U.; Kogarko, L.N. Nd and Sr Isotope Signatures of the Khibina and Lovozero Agpaitic Centres, Kola Alkaline Province, Russia. Lithos 1994, 32, 225-242. [CrossRef]

40. Mitchell, R.H.; Wu, F.-Y.; Yang, Y.-H. In Situ U-Pb, Sr and Nd Isotopic analysis of Loparite by LA-(MC)-ICP-MS. Chem. Geol. 2011, 280, 191-199. [CrossRef]

41. Wu, F.-Y.; Yang, Y.-H.; Marks, M.A.W.; Liu, Z.-C.; Zhou, Q.; Ge, W.-C.; Yang, J.-S.; Zhao, Z.-F.; Mitchell, R.H.; Markl, G. In Situ $\mathrm{U}-\mathrm{Pb}, \mathrm{Sr}, \mathrm{Nd}$ and Hf Isotopic Analysis of Eudialyte by LA-(MC)-ICP-MS. Chem. Geol. 2010, 273, 8-34. [CrossRef]

42. Korchak, Y.A.; Men'shikov, Y.P.; Pakhomovskii, Y.A.; Yakovenchuk, V.N.; Ivanyuk, G.Y. Trap Formation of the Kola Peninsula. Petrology 2011, 19, 87-101. [CrossRef]

43. Féménias, O.; Coussaert, N.; Brassinnes, S.; Demaiffe, D. Emplacement Processes and cooling history of layered cyclic unit II-7 from the Lovozero Alkaline Massif (Kola Peninsula, Russia). Lithos 2005, 83, 371-393. [CrossRef]

44. Kogarko, L.N.; Williams, C.T.; Woolley, A.R. Compositional Evolution and cryptic variation in Pyroxenes of the Peralkaline Lovozero Intrusion, Kola Peninsula, Russia. Mineral. Mag. 2006, 70, 347-359. [CrossRef]

45. Kogarko, L.N.; Lahaye, Y.; Brey, G.P. Plume-Related Mantle Source of Super-Large Rare Metal Deposits from the Lovozero and Khibina Massifs on the Kola Peninsula, Eastern Part of Baltic Shield: Sr, Nd and Hf Isotope Systematics. Miner. Petrol. 2010, 98, 197-208. [CrossRef]

46. Kogarko, L.N. Geochemistry of Fractionation of Coherent Elements (Zr and Hf) during the Profound Differentiation of Peralkaline Magmatic Systems: A Case Study of the Lovozero Complex. Geochem. Int. 2016, 54, 1-6. [CrossRef]

47. Chakhmouradian, A.R.; Mitchell, R.H. New data on Pyrochlore- and Perovskite-Group Minerals from the Lovozero Alkaline Complex, Russia. Eur. J. Mineral. 2002, 14, 821-836. [CrossRef]

48. Ermolaeva, V.N.; Pekov, I.V.; Chukanov, N.V.; Zadov, A.E. Thorium Mineralization in Hyperalkaline Pegmatites and Hydrothermalites of the Lovozero Pluton, Kola Peninsula. Geol. Ore Depos. 2007, 49, 758-775. [CrossRef]

49. Pakhomovsky, Y.A.; Ivanyuk, G.Y.; Yakovenchuk, V.N. Loparite-(Ce) in Rocks of the Lovozero Layered Complex at Mt. Karnasurt and Mt. Kedykvyrpakhk. Geol. Ore Depos. 2014, 56, 685-698. [CrossRef]

50. Pakhomovsky, Y.A.; Panikorovskii, T.L.; Yakovenchuk, V.N.; Ivanyuk, G.Y.; Mikhailova, J.A.; Krivovichev, S.V.; Bocharov, V.N.; Kalashnikov, A.O. Selivanovaite, $\mathrm{NaTi}_{3}(\mathrm{Ti}, \mathrm{Na}, \mathrm{Fe}, \mathrm{Mn})_{4}\left[\left(\mathrm{Si}_{2} \mathrm{O}_{7}\right)_{2} \mathrm{O}_{4}\left(\mathrm{OH}, \mathrm{H}_{2} \mathrm{O}\right)_{4}\right] \cdot \mathrm{nH}_{2} \mathrm{O}$, a New Rock-Forming Mineral from the Eudialyte-Rich Malignite of the Lovozero Alkaline Massif (Kola Peninsula, Russia). Eur. J. Mineral. 2018, 30, 525-535. [CrossRef] 
51. Mikhailova, J.A.; Pakhomovsky, Y.A.; Panikorovskii, T.L.; Bazai, A.V.; Yakovenchuk, V.N. Eudialyte Group Minerals from the Lovozero Alkaline Massif, Russia: Occurrence, Chemical Composition, and Petrogenetic Significance. Minerals 2020, 10, 1070. [CrossRef]

52. Kogarko, L.N.; Nielsen, T.F.D. Compositional Variation of Eudialyte-Group Minerals from the Lovozero and Ilímaussaq Complexes and on the Origin of Peralkaline Systems. Minerals 2021, 11, 548. [CrossRef]

53. Suk, N.I.; Kotel'nikov, A.R.; Koval'skii, A.M. Mineral Thermometry and the Composition of Fluids of the Sodalite Syenites of the Lovozero Alkaline Massif. Petrology 2007, 15, 441-458. [CrossRef]

54. Mikhailova, J.A.; Ivanyuk, G.Y.; Kalashnikov, A.O.; Pakhomovsky, Y.A.; Bazai, A.V.; Yakovenchuk, V.N. Petrogenesis of the Eudialyte Complex of the Lovozero Alkaline Massif (Kola Peninsula, Russia). Minerals 2019, 9, 581. [CrossRef]

55. Lafuente, B.; Downs, R.T.; Yang, H.; Stone, N. The power of databases: The RRUFF project. Highlights Mineral. Crystallogr. 2015, $1-30$.

56. StatSoft Inc. Statistica 13. Available online: www.statsoft.ru (accessed on 19 June 2018).

57. Reyment, R.A.; Jvreskog, K.G. Applied Factor Analysis in the Natural Sciences; Cambridge University Press: Cambridge, UK, 1996.

58. Johnsen, O.; Grice, J.D. The crystal chemistry of the eudialyte group. Can. Mineral. 1999, 37, 865-891.

59. Atencio, D.; Andrade, M.B.; Christy, A.G.; Giere, R.; Kartashov, P.M. The pyrochlore supergroup of minerals: Nomenclature. Can. Mineral. 2010, 48, 673-698. [CrossRef]

60. Higgins, M.D. Quantitative Textural Measurements in Igneous and Metamorphic Petrology; Cambridge University Press: Cambridge, UK, 2006.

61. Kogarko, L. Chemical composition and petrogenetic implications of apatite in the Khibiny apatite-nepheline deposits (Kola Peninsula). Minerals 2018, 8, 532. [CrossRef]

62. Kostyleva-Labuntsova, E.E.; Borutskii, B.E.; Sokolova, M.N.; Shlykova, Z.V. Mineralogy of the Khibiny Massif: Minerals; Nauka: Moscow, Russia, 1978.

63. Yakovenchuk, V.N.; Ivanuyk, G.Y.; Konopleva, N.G.; Korchak, Y.A.; Pakhomovsky, Y.A. Nepheline of the Khibiny alkaline massif (Kola Peninsula). ZVMO 2010, 139, 80-91.

64. Hamilton, D.L. Nephelines as Crystallization Temperature Indicators. J. Geol. 1961, 69, 321-329. [CrossRef]

65. Hawthorne, F.C.; Oberti, R.; Harlow, G.E.; Maresch, W.V.; Martin, R.F.; Schumacher, J.C.; Welch, M.D. Nomenclature of the Amphibole Supergroup. Am. Mineral. 2012, 97, 2031-2048. [CrossRef]

66. Locock, A.J. An excel spreadsheet to classify chemical analyses of Amphiboles following the IMA 2012 recommendations. Comput. Geosci. 2014, 62, 1-11. [CrossRef]

67. Pfaff, K.; Krumrei, T.; Marks, M.; Wenzel, T.; Rudolf, T.; Markl, G. Chemical and physical evolution of the 'lower layered sequence' from the nepheline syenitic ilímaussaq intrusion, South Greenland: Implications for the origin of magmatic layering in peralkaline felsic liquids. Lithos 2008, 106, 280-296. [CrossRef]

68. Grant, J.A. The Isocon Diagram; a Simple Solution to Gresens' Equation for Metasomatic Alteration. Econ. Geol. 1986, 81, 1976-1982. [CrossRef]

69. Shannon, R.D. Revised effective ionic radii and systematic studies of interatomic distances in halides and chalcogenides. Acta Crystallogr. Sect. A 1976, 32, 751-767. [CrossRef]

70. Webster, J.D. Partitioning of $\mathrm{F}$ between $\mathrm{H}_{2} \mathrm{O}$ and $\mathrm{CO}_{2}$ fluids and topaz rhyolite melt. Contrib. Mineral. Petrol. 1990, 104, 424-438. [CrossRef]

71. Dolejš, D.; Baker, D.R. Liquidus Equilibria in the System $\mathrm{K}_{2} \mathrm{O}-\mathrm{Na}_{2} \mathrm{O}-\mathrm{Al}_{2} \mathrm{O}_{3}-\mathrm{SiO}_{2}-\mathrm{F}_{2} \mathrm{O}_{-1}-\mathrm{H}_{2} \mathrm{O}$ to 100 MPa: I. Silicate-Fluoride Liquid Immiscibility in Anhydrous Systems. J. Petrol. 2007, 48, 785-806. [CrossRef]

72. Dolejš, D.; Zajacz, Z. Halogens in silicic magmas and their hydrothermal systems. In The Role of Halogens in Terrestrial and Extraterrestrial Geochemical Processes; Harlov, D.E., Aranovich, L., Eds.; Springer International Publishing: Cham, Switzerland, 2018; pp. 431-543, ISBN 978-3-319-61665-0.

73. Preston, R.F.; Stevens, G.; McCarthy, T.S. Fluid Compositions in equilibrium with silica-undersaturated magmas in the system $\mathrm{Na}_{2} \mathrm{O}-\mathrm{Al}_{2} \mathrm{O}_{3}-\mathrm{SiO}_{2}-\mathrm{H}_{2} \mathrm{O}$ : Clues to the composition of fenitizing fluids. Contrib Mineral. Petrol. 2003, 144, 559-569. [CrossRef]

74. Baudouin, C.; Parat, F. Role of volatiles $\left(\mathrm{S}, \mathrm{Cl}, \mathrm{H}_{2} \mathrm{O}\right)$ and silica activity on the crystallization of Haüyne and Nosean in Phonolitic magmas (Eifel, Germany and Saghro, Morocco). Am. Mineral. 2015, 100, 2308-2322. [CrossRef]

75. Potter, J.; Salvi, S.; Longstaffe, F.J. Abiogenic Hydrocarbon isotopic signatures in granitic rocks: Identifying pathways of formation. Lithos 2013, 182-183, 114-124. [CrossRef]

76. Nivin, V.A.; Treloar, P.J.; Konopleva, N.G.; Ikorsky, S.V. A Review of the Occurrence, Form and Origin of C-Bearing Species in the Khibiny Alkaline Igneous Complex, Kola Peninsula, NW Russia. Lithos 2005, 85, 93-112. [CrossRef]

77. Salvi, S.; Williamsjones, A. Alteration, HFSE Mineralisation and hydrocarbon formation in Peralkaline Igneous systems: Insights from the Strange Lake Pluton, Canada. Lithos 2006, 91, 19-34. [CrossRef]

78. Ivanyuk, G.; Yakovenchuk, V.; Pakhomovsky, Y.; Konoplyova, N.; Kalashnikov, A.; Mikhailova, J.; Goryainov, P. Self-Organization of the Khibiny Alkaline Massif (Kola Peninsula, Russia). In Earth Sciences; Dar, I.A., Ed.; InTech: Rijeka, Croatia, 2012; ISBN 978-953-307-861-8.

79. Inanyuk, G.Y.; Goryanov, P.M.; Pakhomovsky, Y.A.; Konopleva, N.G.; Yakovenchuk, V.N.; Bazai, A.V.; Kalashnikov, A.O. Selforganization of ore complexes. In Synergetic Principles of Forecasting and Prospecting for Mineral Deposits; GEOKART-GEOS: Moscow, Russia, 2009. 
80. Tikhonenkov, I.P. Nepheline Syenites and Pegmatites of the Khibiny Massif and the Role of Postmagmatic Phenomena in Their Formation; Nauka: Moscow, Russia, 1963.

81. Sorensen, H.; Bohse, H.; Bailey, J. The origin and mode of emplacement of lujavrites in the Ilímaussaq Alkaline complex, South Greenland. Lithos 2006, 91, 286-300. [CrossRef]

82. Sørensen, H The Ilímaussaq alkaline complex, South Greenland: Status of mineralogical research with new results. Geol. Greenl Surv. Bull. 2001, 190, 1-167. 